\title{
Palaeomagnetism and magnetic fabrics of the Late Palaeozoic volcanism in the Castejón-Laspaúles basin (Central Pyrenees). Implications for palaeoflow directions and basin configuration
}

\author{
ESTHER IZQUIERDO-LLAVALL*†, ANTONIO CASAS-SAINZ*, \\ BELÉN OLIVA-URCIA \& \&OBERT SCHOLGER § \\ * Departamento de Ciencias de la Tierra, Universidad de Zaragoza, 50009 Zaragoza, Spain \\ $\ddagger$ Geo-environmental Processes and Global Change, IPE-CSIC, Zaragoza, Spain \\ $\S$ Chair of Applied Geophysics, University of Leoben, Leoben, Austria
}

(Received 6 March 2013; accepted 27 August 2013; first published online 7 November 2013)

\begin{abstract}
The Castejón-Laspaúles basin is one of the South Pyrenean basins of Late Variscan age that were strongly inverted during the Alpine compression (Late Cretaceous-Tertiary). It is mainly composed by Stephanian pyroclastic and volcanic deposits that reach a maximum thickness of $\sim 500 \mathrm{~m}$, and are overlain by Permian and Triassic sedimentary units. A palaeomagnetic and magnetic fabrics (AMS) study was carried out in the Stephanian units, where the general absence of flow markers at the outcrop scale and the Alpine inversional structure prevent the straightforward reconstruction of the original volcanic and basinal configuration. Magnetic fabric data are not overprinted by Alpine internal deformation and can be interpreted in terms of primary volcanic and pyroclastic fabrics. The obtained directions coincide in the different sampled units, suggesting a constant source area during the development of the basin, and show the dominance of $\mathrm{N}-\mathrm{S}$-trending $\mathrm{K}_{1}$ axes that are interpreted to be parallel to flow directions. Palaeomagnetic data indicate the presence of a pre-folding palaeomagnetic component that is rotated clockwise by an average of $+37^{\circ}\left( \pm 32^{\circ}\right)$ with regards to the Stephanian reference. This rotation probably took place during Alpine thrusting since it is also registered by the overlying Triassic deposits. The whole dataset is interpreted in terms of basin development under sinistral transtension with two main fault sets: deep-rooted E-W-striking faults, probably responsible for magmatic emissions, and shallow-rooted, listric faults of $\mathrm{N}-\mathrm{S}$ orientation.
\end{abstract}

Keywords: magnetic fabrics, palaeomagnetism, volcanism, Stephanian, Pyrenees.

\section{Introduction}

The Late Palaeozoic (Stephanian to Permian times) is one of the most important stages of volcanic activity in western Europe and the Tethys realm (Arthaud \& Matte, 1977; Stampfli et al. 1998; McCann et al. 2006; Bourquin et al. 2007). However, in the Iberian plate a complete palaeogeographical picture of the setting of active faults and volcanic sources is not available yet because of the scarcity of outcrops and the difficulty of interpreting some of them owing to post-basinal compressional stages.

In the Pyrenean range, the Stephanian-Permian units occur as discontinuous outcrops of volcanic and continental deposits showing important thickness variations. These rocks were deposited in small and variably spaced intra-mountainous basins (J. Gisbert, unpub. Ph.D. thesis, Univ. Zaragoza, 1981; Aso et al. unpub. technical report, Instituto Geológico y Minero de España, 1987; B. Valero-Garcés, unpub. Ph.D. thesis, Univ. Zaragoza, 1991; Fig. 1a), where sedimentation was strongly controlled by the activity of faulted margins and volcanism played an important role (Martí $\&$ Mitjavila, 1987, 1988). Several studies deal with the

†Author for correspondence: estheriz@unizar.es geometry and dynamics of these basins and speculate on the causes of their origin (Soula, Lucas \& Bessiere, 1979; J. Gisbert, unpub. Ph.D. thesis, Univ. Zaragoza, 1981; Bixel \& Lucas, 1983; Speksnijder, 1985). Nonetheless, this topic is still controversial and different geodynamic scenarios are evoked by the different authors: the basins are interpreted to be related to regional transtension or transpression (Soula, Lucas \& Bessiere, 1979; Gisbert, 1984; Lago et al. 2004; Román-Berdiel et al. 2004; Cantarelli et al. 2009, in press; Rodríguez, Cuevas \& Tubía, 2012), to extension (Saura \& Teixell, 2006) or to both regimes (Arthaud \& Matte, 1977; Ziegler, 1988; Stampfli et al. 1998). There are also some open questions regarding the geometry and dynamics of the Stephanian, volcanic-dominated basins (Bixel \& Lucas, 1983; Martí \& Mitjavila, 1987, 1988; Lago et al. 2004), where the massive nature of most of the volcanic and pyroclastic rocks makes difficult the determination of their internal structure and the recognition of flow directions, especially at the mesoscale.

In this work we use the anisotropy of the magnetic susceptibility (AMS) and palaeomagnetic methods as a source of information to reconstruct and to better constrain the tectonic setting and internal geometry of the volcanic rocks in the Castejón-Laspaúles Stephanian basin (Fig. 1). On the one hand, AMS studies on lava 

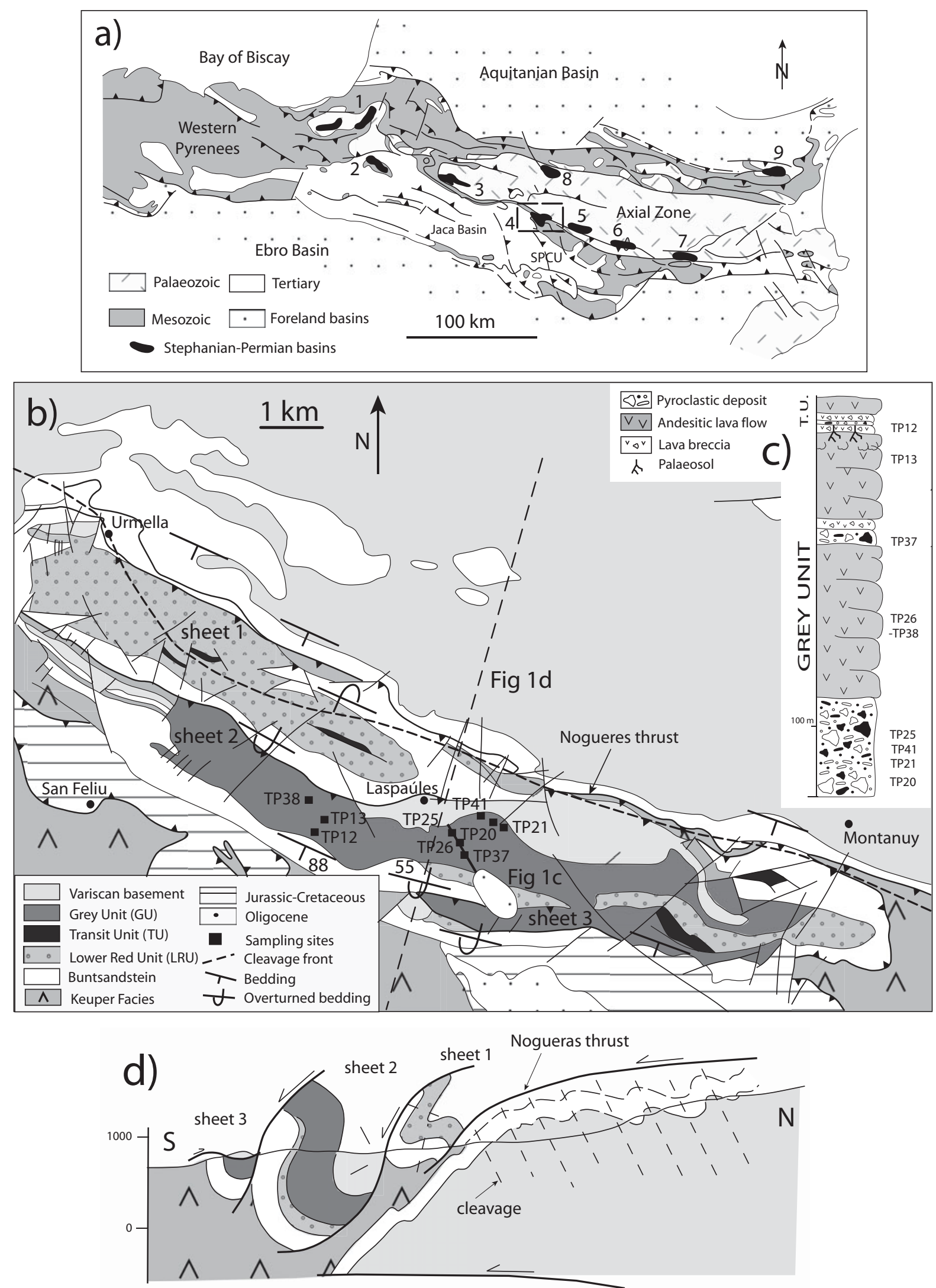

Figure 1. (a) Geological sketch of the Pyrenees showing location of the Stephanian-Permian basins (modified from Teixell, 1996); 1 Basque basin, 2 - Pamplona basin, 3 - Aragón-Béarn basin, 4 - Castejón-Laspaúles basin, 5 - Malpàs-Sort basin, 6 - Cadí basin, 7 Castellar-Camprodón basin, 8 - Central French basin, 9 - Eastern French basin (after J. Gisbert, unpub. Ph.D. thesis, Univ. Zaragoza, 1981). (b) Detailed geological map of the study area (modified from Aso et al. unpub. technical report, Instituto Geológico y Minero de España, 1987) including location of the sampling sites. (c) Stratigraphic log across the central part of thrust sheet 2 (Grey Unit), based on the description of Aso et al. (unpub. technical report, Instituto Geológico y Minero de España, 1987). (d) Geological cross-section (modified from Séguret, 1972). The location of the cross-section and the stratigraphic log is indicated in (b). 
flows and pyroclastic rocks (ignimbrites, pyroclastic surge deposits) have shown that their magnetic fabric is indicative of flow patterns and are therefore useful to locate the possible source areas (Ellwood, 1978; Incoronato et al. 1983; Knight et al. 1986; CañónTapia, Walker \& Herrero-Bervera, 1996; Cagnoli \& Tarling, 1997; Paquereau-Lebti et al. 2008; MacDonald et al. 2012). On the other hand, palaeomagnetic techniques are consolidated as a powerful tool to detect vertical axis rotations (VARs) (Allerton, 1998; Pueyo, Millán \& Pocoví, 2002; Platt et al. 2003; Pueyo et al. 2004; Weil \& Sussman, 2004; Oliva-Urcia \& Pueyo, 2007; Sussman et al. 2012) and therefore accurately reconstruct the actual orientation of palaeoflow directions in absolute and relative frames.

The Castejón-Laspaúles basin is an a priori interesting basin to apply palaeomagnetic and rock magnetic analyses to because of (i) the varied nature of its filling (pyroclastic, sedimentary and lava flows), (ii) the thickness of the volcanic sequence, reaching $500 \mathrm{~m}$ in depocentral areas and (iii) the complex, post-basinal structure acquired during Tertiary times that makes difficult its reconstruction by means of conventional techniques.

\section{Geological setting}

The Castejón-Laspaúles basin belongs to the Nogueres Zone, located in the southern part of the Pyrenean Axial Zone, and limited to the south by the Jurassic, Cretaceous and Tertiary rocks of the South Pyrenean Central Unit (SPCU) (Fig. 1a). In this sector of the Pyrenean range, Stephanian-Permian units occur as discontinuous outcrops unconformably overlying the Variscan units of the Axial Zone (Gisbert, 1983; Gisbert, Martí \& Gascón, 1985) (Fig. 1a).

The Castejón-Laspaúles basin has an $\sim 800 \mathrm{~m}$ preserved thickness of syn-rift sedimentary and volcanic rocks (Valero-Garcés \& Gisbert-Aguilar, 2004) and extends for $\sim 17 \mathrm{~km}$ along strike (WNW-ESE direction) (Fig. 1b). Following Gisbert (unpub. Ph.D. thesis, Univ. Zaragoza, 1981), the Stephanian-Permian succession in this sector of the Pyrenees is divided in three units: (1) the 'grey unit', GU (Stephanian age), (2) the 'transit unit', TU (Stephanian-Autunian) and (3) the 'lower red unit' (LRU) (Autunian-Saxonian). The GU is more than $500 \mathrm{~m}$ thick and is constituted by pyroclastic deposits and dark-coloured lava flows of basaltic andesites (Aso et al. unpub. technical report, Instituto Geológico y Minero de España, 1987; García Senz et al. 2009a,b) (Fig. 1c). The TU appears only as discontinuous outcrops of reduced thickness, including fine-grained sandstones, lacustrine shales, coal layers and pyroclastic rocks, that evolve laterally to fanglomerate deposits. In these deposits palaeocurrents are directed towards the south (García Senz et al. 2009b). The LRU (also called the Peranera Formation; Nagtegaal, 1969) is represented by more than $200 \mathrm{~m}$ of red shales and locally interbedded layers of sandstones and microconglomerates. This unit is unconformably covered by continental red beds, mainly sandstones, siltstones and shales, of Early to Middle Triassic age (Buntsandstein facies).

The Castejón-Laspaúles basin was inverted during the Pyrenean compression (Late Cretaceous to Tertiary times) and transported southwards within the Nogueres thrust sheet (Fig. 1b, d). In the study area, this main thrust is subdivided into three smaller-scale thrust sheets that are folded by underlying basement thrusts and involved in a foreland-dipping system at the front of an antiformal stack forming the Axial Zone. They are related to forelandward-rotated synformal anticlines (têtes plongeantes; Séguret, 1972). The northernmost thrust sheet (sheet 1 in Fig. 1b) contains mainly continental deposits from the LRU whereas the GU crops out within the central and southernmost thrust sheets (sheets 2 and 3 in Fig. 1b). In map view, the southern thrust sheets are shifted towards the east with respect to the thrust sheets located in a more northern position.

Thrusting was accompanied by the development of ESE-WNW-trending, S-verging folds, related to a pervasive cleavage affecting the Triassic and Palaeozoic units in the footwall of the Nogueres thrust and, partially, the Triassic and Permian rocks in the hangingwall (see the location of the cleavage front in Fig. 1b). The sampled volcanic and pyroclastic units are located South of the cleavage front and therefore not affected by macroscopic cleavage development.

\section{Dynamics of the Stephanian-Permian basins in the Pyrenees}

In spite of the controversy about the tectonic regime acting in the Pyrenees during Stephanian-Permian times, there is a general agreement on the influence of strikeslip faulting. Soula, Lucas \& Bessiere (1979) proposed that the development of the French Permian basins occurred during simple shear along previous basement faults of Variscan origin. The fault planes were subvertical, $\mathrm{N} 030^{\circ} \mathrm{E}$ - and $\mathrm{N} 070^{\circ} \mathrm{E}$-striking, and the opening of the basins took place by block rotation under a general sinistral shearing (Fig. 2a). Bixel \& Lucas (1983) described the western basins (AragónBearn and Basque basins) as $\mathrm{E}-\mathrm{W}$ and $\mathrm{N}-\mathrm{S}$ halfgrabens, whose opening was related to transcurrent shear. The basins were controlled by $\mathrm{N}-\mathrm{S}$-striking normal faults during the Stephanian, under a general dextral shear, and NE-SW-striking extensional faults during the Permian, under an overall sinistral wrench regime (Fig. 2b). Speksnijder (1985) proposed for La Seu basin a simple shear mechanism along E-Wstriking, dextral faults that generated E-W-oriented, strike-slip grabens, with alternating stages of transtension and transpression that were responsible for intrabasinal unconformities (Fig. 2c). Gisbert (unpub. Ph.D. thesis, Univ. Zaragoza, 1981) characterized also the activity of E-W-striking, sinistral transcurrent faults during the Stephanian and Early Permian, controlling the geometry of basins (Fig. 2d). Nonetheless, Saura 


\section{Sedimentary basins}

a) Soula et al., 1979. French basins

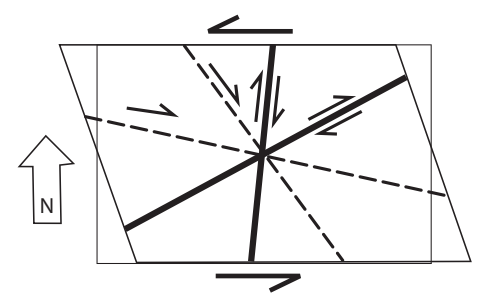

b) Bixel and Lucas (1983). Western Pyrenees

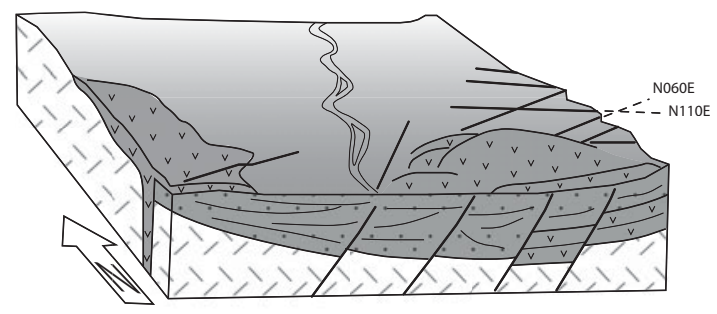

c) Speksnijdeer (1985). La Seu basin

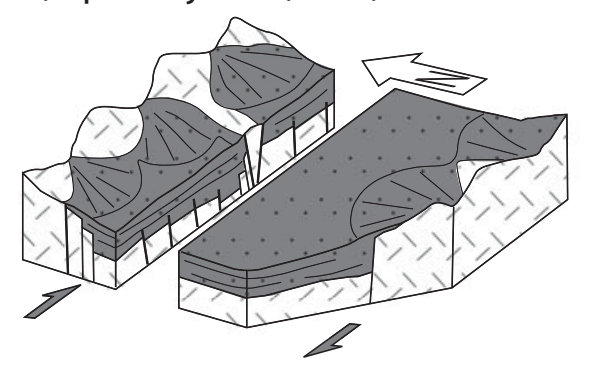

d) Gisbert $(1981,1986)$. Eastern Pyrenees

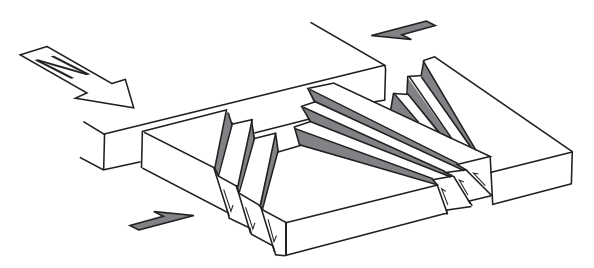

e) Saura and Teixell (2006). Nogueres Zone

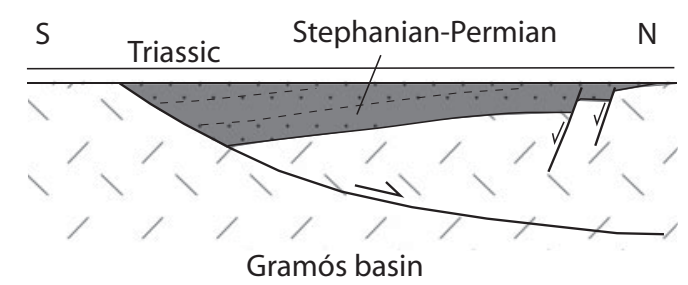

f) Martí and Mitjavila (1988). Catalonian Pyrenees

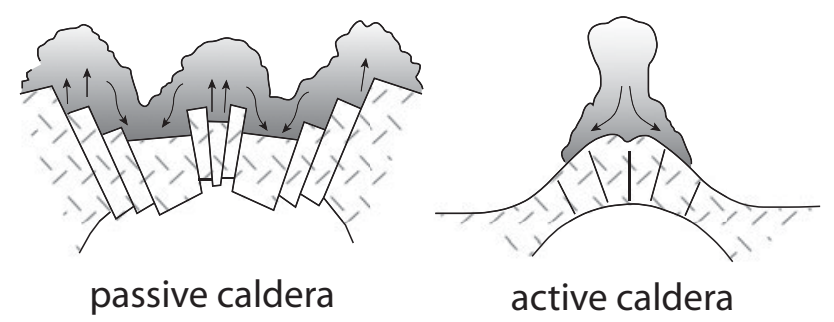

Figure 2. Different models proposed for the Stephanian-Permian basins in the Pyrenees (modified from Soula, Lucas \& Bessiere, 1979; Bixel \& Lucas, 1983; Speksnijder, 1985; J. Gisbert, unpub. Ph.D. thesis, Univ. Zaragoza, 1981; Martí \& Mitjavila, 1988; Saura \& Teixell, 2006).

\& Teixell (2006) interpreted the Stephanian-Permian basins located to the east of the study area (Erill Castell, Gramós and Estac basins) as extensional asymmetric grabens or half-grabens (Fig. 2e), controlled by normal E-W-striking faults acting as basin boundaries.

With regards to the volcanic basin activity, Martí \& Mitjavila $(1987,1988)$ proposed that the MalpàsSort, Cadí and Nevà-Campellas-Bruguera basins (eastern Pyrenees) behaved as passive volcanic calderas, with emissions of large volumes of magma and materials resulting from hydromagmatic processes. The geometry of these calderas was conditioned by the previous basin geometry, since the output of magma took place through the normal faults delimiting basin boundaries (Fig. 2f). On the other hand, the Castellar de N'Hug-Camprodón basin behaved as a sedimentary basin related to an active volcanic caldera on its western boundary (Fig. 2f). Towards the Western Pyrenees, the volcanic complexes show extrusive flows, but also important intrusive bodies. In the Anayet basin, volcanism is mainly represented by a thick laccolith that spreads laterally forming at least two sills, whereas in the Aragón-Subordán area a $35 \mathrm{~m}$ thick sill crops out (Lago et al. 2004).

\section{Methodology}

The samples used to analyse the magnetic fabrics and palaeomagnetism were directly drilled in the field with a gasoline-powered drill machine refrigerated with water. Nine sites, stratigraphically and areally distributed throughout the volcanic outcrops of the CastejónLaspaúles basin, were collected. The samples belong to different kinds of pyroclastic units and andesitic lava flows and are located in thrust sheet 2 (see Fig. 1b), where the whole stratigraphic sequence is overturned (Fig. 1d). Between 12 and 21 cores were drilled in each 
sampling site, distributed in $\sim 5$ to 50 m of stratigraphic succession, and avoiding sampling close to the base or the top of the volcanic flows or ignimbritic sequences. The samples were oriented using a magnetic compass. Bedding/flow plane data were measured in the field for every sampling site. In site TP37, a conglomerate test was performed.

\section{4.a. Magnetic mineralogy}

In order to determine the magnetic mineralogy, three different analyses were performed: (1) temperaturedependent susceptibility curves, (2) isothermal remanent magnetization (IRM) and backfield acquisition curves (Dunlop, 1972), and (3) stepwise thermal demagnetization of composite IRM (Lowrie, 1990).

Temperature-dependent susceptibility curves between -195 and $700{ }^{\circ} \mathrm{C}$ were carried out in nine selected samples (one sample per site). At high temperatures, the variation of susceptibility with temperature allows the identification of magnetic phases based on their Curie $\left(T_{\mathrm{c}}\right)$ or Néel temperature $\left(T_{\mathrm{N}}\right)$ that defines the transition from ferromagnetic or antiferromagnetic to paramagnetic behaviours. This transition temperature is different for different ferromagnetic (sensu lato) minerals. At low temperatures, the mineral identification is based on slope variations related to changes in the crystallographic structure of the mineral (e.g. Verwey transition in magnetite at $-152{ }^{\circ} \mathrm{C}$; Verwey, 1939).

A KLY-3 Kappabridge combined with a CS-3 furnace (temperature range between 40 and $700{ }^{\circ} \mathrm{C}$ ) and a CLS apparatus (temperature range between $-195^{\circ}$ and $0{ }^{\circ} \mathrm{C}$ ) (AGICO Inc., Czech Republic) was used for the temperature-dependent magnetic susceptibility (K$T$ ) curves. Heating/cooling rates range between 11 and $14{ }^{\circ} \mathrm{C} \mathrm{min}^{-1}$, respectively. The curves above room temperature were performed in an argon atmosphere in order to avoid mineral oxidations. Curie temperatures were determined following the method of Petrovský \& Kapička (2006).

To determine the carriers of the palaeomagnetic components, IRM and backfield acquisition curves, combined with thermal demagnetization of composite IRM, were conducted using a pulse magnetizer (maximum field of $2.5 \mathrm{~T}$ ). The IRM acquisition curves were analysed by means of the IRM-CLG 1.0 worksheet (Kruiver, Dekkers \& Heslop, 2001) that allows the quantification of the magnetic coercivity and the relative contribution to the IRM of the different components. Four samples (from four different sampling sites) were selected to carry out the IRM acquisition curves. They belong to different lithological types and cover the whole range of natural remanent magnetization (NRM) values and unblocking temperatures. Thermal demagnetization of composite IRM was performed in one sample per site. Three different, decreasing magnetic fields $(1.5,0.4$ and $0.12 \mathrm{~T})$ were applied along the three axes of the standard samples.

\section{4.b. Magnetic fabrics at room and low temperatures}

The magnetic susceptibility $(\mathrm{K})$ of a rock is the ratio of induced magnetization (M) to an applied magnetic field $(\mathrm{H}): \mathrm{M}=\mathrm{K} \cdot \mathrm{H}$. This physical property is described by a second-rank tensor and represented by an ellipsoid, which is defined by its three principal axes: maximum $\left(\mathrm{K}_{1}\right)$, intermediate $\left(\mathrm{K}_{2}\right)$ and minimum $\left(\mathrm{K}_{3}\right)$. The orientation of the ellipsoid is mostly dependent on the crystallographic preferred orientation or the shape of the magnetic carriers.

In undeformed lavas, and away from the end of the flow, the mean magnetic foliation (perpendicular to the minimum axis) usually lies close to the flow plane, and the maximum susceptibility axis can be parallel (flow emplaced on significant slope) or perpendicular (flow emplaced on very weak slope) to the flow direction (Khan, 1962; Halvorsen, 1974; Ellwood, 1978; Cañón-Tapia, Walker \& Herrero-Bervera, 1996; Henry, Plenier \& Camps, 2003; Cañón-Tapia, 2004). The magnetic foliation can exhibit a small imbrication angle relative to the flow plane that is upflow dipping in the lower part of the flow or downflow dipping in its lower part (Cañón-Tapia, Walker \& Herrero-Bervera, 1996, 1997). In pyroclastic rocks, the direction of the $K_{\text {min }}$ axis is perpendicular to the bedding plane and the $\mathrm{K}_{\max }$ axis is commonly parallel to the flow direction (Knight et al. 1986; MacDonald \& Palmer, 1990; PaquereauLebti et al. 2008), but flows perpendicular to $\mathrm{K}_{\max }$ axis directions have also been reported (Cagnoli \& Tarling, 1997). When $K_{\max }$ is flow-parallel (and if there is no tectonic tilt at the site), the magnetic lineation coincides with the direction of maximum dip of the foliation plane. The slightly inclined foliation plane is usually interpreted to represent imbrication, and therefore the direction of maximum dip of the foliation plane can be used to determine flow directions.

The shape of the ellipsoid and degree of development of magnetic fabric are defined by means of two parameters: (1) the corrected anisotropy degree, $\mathrm{Pj}$, and (2) the shape parameter, T, varying between $\mathrm{T}=-1$ (prolate ellipsoids) and $\mathrm{T}=+1$ (oblate ellipsoids). $\mathrm{Pj}$ and $\mathrm{T}$ are defined as (Jelinek, 1981):

$$
\begin{gathered}
P_{j}=\exp \sqrt{\left.\left\{2\left[\left(\mu_{1}-\mu_{m}\right)^{2}+\left(\mu_{2}-\mu_{m}\right)^{2}\right\}+\left(\mu_{3}-\mu_{m}\right)^{2}\right]\right\}} \\
T=\frac{\left(2 \mu_{2}-\mu_{1}-\mu_{3}\right)}{\left(\mu_{1}-\mu_{3}\right)}
\end{gathered}
$$

where $\mu_{1}=\ln K_{1}, \mu_{2}=\ln K_{2}, \mu_{3}=\ln K_{3}$, and $\mu_{m}=$ $\left(\mu_{1}+\mu_{2}+\mu_{3}\right) / 3$.

The AMS at room temperature was measured in 141 standard rock samples $(2.5 \mathrm{~cm}$ in diameter, $2.1 \mathrm{~cm}$ in height) with an average of 16 samples per site. The measurements were done with a KLY3S (AGICO Inc., Czech Republic) in the laboratory of the University of Zaragoza.

The analyses of low-temperature AMS (LT-AMS) were performed on samples from four selected sites, including pyroclastic deposits and lava flows. Samples were cooled down in liquid nitrogen $(\sim 77 \mathrm{~K})$ for a 
minimum time of 30 minutes. The magnetic susceptibility was measured in air using the KLY3S, and the samples were cooled down again for ten minutes before the measurement in each new position (as in Lüneburg et al. 1999).

Low temperatures enhance the magnetic susceptibility of paramagnetic minerals, as established by the Curie-Weiss law $\left(\mathrm{K}=\mathrm{C} /\left(T-T_{\mathrm{C}}\right)\right.$, where $\mathrm{K}$ is the magnetic susceptibility, $\mathrm{C}$ is the Curie constant, $T$ is the absolute temperature and $T_{\mathrm{C}}$ is the Curie temperature). Assuming purely paramagnetic phases with a paramagnetic Curie temperature of around $0 \mathrm{~K}$, the expected magnetic susceptibility is approximately 3.8 times higher at $\sim 77 \mathrm{~K}$ (LT-AMS) than at room temperature.

\section{4.c. Image analyses}

Image analysis was performed in six samples from different sites. For each site, bi-dimensional orientation analyses were applied in thin-sections, which were taken from three perpendicular planes preferentially oriented with respect to the AMS ellipsoid axes: one plane is parallel to the magnetic foliation (perpendicular to $\mathrm{K}_{3}$ ) and the two remaining planes are perpendicular and contain $K_{1}$ and $K_{2}$ axes, respectively. In this way, the meaning of AMS in terms of mineral orientation can be better defined than with three randomly oriented perpendicular planes (Oliva-Urcia et al. 2012a; Izquierdo-Llavall et al. 2012b). The ImageJ public domain program (http://rsbweb.nih.gov/ij/ index.html) was used to measure the shape preferred orientations (SPO) of the different components forming the volcanic and pyroclastic deposits (pyroclastic and lithic fragments, darker minerals, glass fragments, etc). The ImageJ software allows the approximation of the shapes of the fragments and individual mineral grains to ellipses and the measurement of the direction of their maximum axes. The determination of the SPO in three perpendicular planes has been used to reconstruct the bedding or flow plane, in order to compare it with the field data and the magnetic fabric results.

\section{4.d. Palaeomagnetism}

Both alternating field (AF) demagnetization and stepwise thermal demagnetization of the NRM were carried out at the Gams Palaeomagnetic Laboratory (Leoben University, Austria). Magnetization was measured using a 2G DC-SQUID magnetometer, and a MMTD-1 oven was used to thermally demagnetize the samples in steps ranging from 10 to $200^{\circ} \mathrm{C}$. AF demagnetization was performed by means of a $2 \mathrm{G}$ alternating field demagnetizer, in field steps ranging from 3 to $10 \mathrm{mT}$ up to a maximum field of $120 \mathrm{mT}$. An average of 8-9 standard samples per site was measured. Palaeomagnetic components were fitted using the PCA method and site means were computed using Fisher (1953) statistics. In both cases, the routine provided by the software Remasoft (Chadima \& Hrouda, 2006) was used.
A 'conglomerate test' was performed at site TP37, where an ignimbritic sequence containing centimetric to decimetric-size, sub-angular andesitic lithic clasts crops out. The andesitic fragments probably derive from the underlying lava flows and were incorporated into the ignimbritic sequence during its deposition. In this site, samples from both the matrix and the andesitic lithic clasts were demagnetized.

\section{Results}

\section{5.a. Field and petrographical data}

All the sampling sites considered in this study belong to the GU (Fig. 1b), which shows massive andesites in the western and eastern basin margins (Aso et al. unpub. technical report, Instituto Geológico y Minero de España, 1987) and thick sequences of pyroclastic materials in the basin centre. The sampling sites are distributed within the central domain of the basin, where the following sequence is observed (Aso et al. unpub. technical report, Instituto Geológico y Minero de España, 1987; Fig. 1c): (1) a basal unit 130 m thick, constituted by breccias and thick ignimbritic sequences (sites TP20, TP21, TP25, TP38 and TP41), (2) $200 \mathrm{~m}$ of green andesites (TP26), (3) c. $20 \mathrm{~m}$ of ignimbrites and other pyroclastic deposits (TP37) and (4) c. $130 \mathrm{~m}$ of lava breccias and andesitic lava flows with an interbedded deposit of ignimbrites (TP12 and TP13). The top of the sequence is marked by the development of a thick palaeosol. Nonetheless, palaeosols are absent inside the GU, indicating that the deposition of the whole sequence was a relatively continuous and quick process. The pyroclastic units are mainly constituted by ignimbrites, but other types of deposits such as domebreccias (to the bottom of the sequence) and pyroclastic surges with abundant contents of lithic fragments are also recognized (Aso et al. unpub. technical report, Instituto Geológico y Minero de España, 1987). Deposits are generally massive but flow or bedding planes could be measured in the field for all the sampling sites (Fig. 3a). Unfortunately, the determination of palaeoflow directions at the outcrop scale was not possible.

Nonetheless, the petrographical study reveals the presence of a well-developed flow orientation in most of the samples. The pyroclastic units are strongly heterometric, with highly vesicular volcanic fragments and quartz lithic fragments embedded in a fine-grained chloritic matrix (Fig. 3b). The lava flows show a finer and more homogeneous grain size (Fig. 3c). The main phenocrysts forming the sampled lithologies are plagioclase, opaque minerals, pyroxene, amphibole and, occasionally, olivine and chloritized biotite (Fig. 3c, d). The matrix is mainly composed by plagioclase, chlorite and opaque grains. Calcite cements are common in the pyroclastic rocks, filling in fractures and preferentially oriented vacuoles in vesicular volcanic fragments.

The outcrops of pyroclastic and volcanic deposits are limited to the west by NE-SW-striking faults in the central and southernmost thrust sheets (sheets 2 and 3 in 

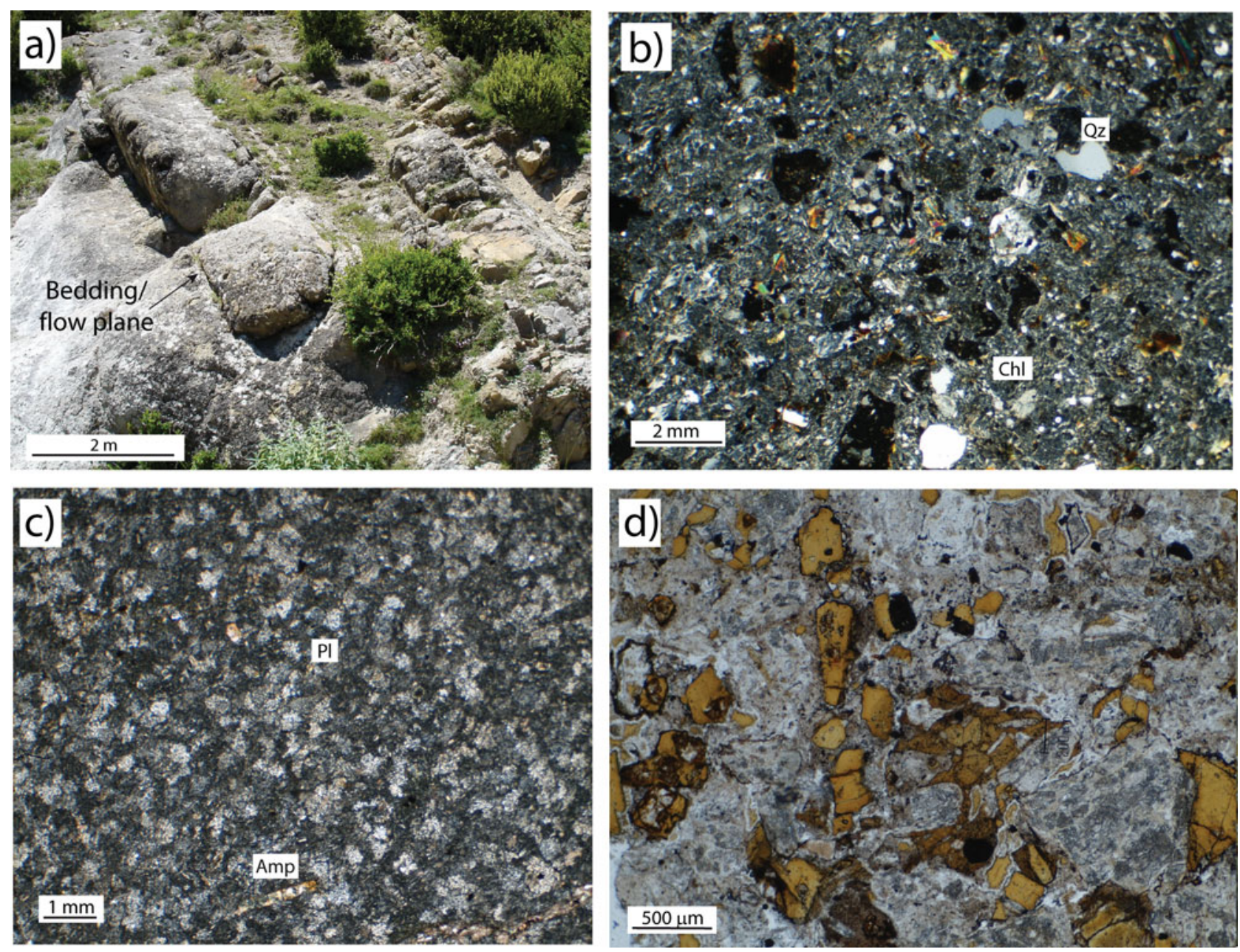

Figure 3. (Colour online) (a) Outcrop of ignimbritic deposits showing a well-defined bedding (site TP25). (b) Ignimbrite constituted by volcanic and lithic fragments embedded in a chloritic (Chl) matrix. Thin-section from site TP37 (crossed nicols). (c) Fine-grained andesitic lava flow mainly composed of plagioclase (Pl) and amphibole (Amp). Thin-section from site TP26 (crossed nicols). (d) Phenocrysts showing a preferred orientation. Thin-section from site TP38 (parallel nicols).

Fig. 1b). The fault affecting the GU in the central thrust sheet (sheet 2) was interpreted as a syn-sedimentary normal fault, active during Stephanian times, since it is unconformably overlain by Triassic deposits (García Senz et al. 2009a,b). This main structure could be syn-kinematic with a set of NNE-SSW- to NE-SWstriking listric normal faults, affecting the Devonian basement of the Nogueres Zone and the Stephanian volcanic rocks (M. P. Bates, unpub. Ph.D. thesis, Univ. Leeds, 1987). These faults strike $\mathrm{N} 020^{\circ} \mathrm{E}$ to $\mathrm{N} 055^{\circ} \mathrm{E}$ and dip both east and west.

\section{5.b. Magnetic susceptibility and magnetic mineralogy}

The sampled rocks show variable bulk magnetic susceptibility values, indicating a great heterogeneity in the mineralogical content of the volcanic and pyroclastic deposits, even in samples from the same site (see standard deviation in Table 1). Bulk magnetic susceptibility $(\mathrm{K})$ ranges between 117 and $415 \cdot 10^{-6}(\mathrm{SI})$, except in site TP12, where an anomalously high value of magnetic susceptibility was measured $\left(1080 \cdot 10^{-6}\right)$ (Table 1).
Temperature-dependent susceptibility measurements indicate, in seven out of nine samples, that magnetic fabrics are carried by a mixture of paramagnetic and ferromagnetic phases (type 1 curves in Fig. 4): they show a concave-hyperbolic shape at the beginning, indicating the contribution of paramagnetic carriers (iron-bearing silicates) and a drop in the magnetic susceptibility at $c .580^{\circ} \mathrm{C}$ ( $T_{\mathrm{C}}$ of magnetite) (Fig. 4a). Only in two of these samples (TP20 and TP41) a second, weak phase was registered as indicated by a slight drop in susceptibility between $670^{\circ}$ and $700^{\circ} \mathrm{C}$ (TP20 is shown in Fig. 4b), suggesting the contribution of haematite in the ferromagnetic content $\left(T_{\mathrm{N}}\right.$ of haematite at $\left.675^{\circ} \mathrm{C}\right)$. The method of Hrouda (1994) allows the estimation of a heterogeneous paramagnetic contribution in type 1 curves, ranging between $50 \%$ (sample TP20) and $93 \%$, and higher than $72 \%$ when magnetite is the only ferromagnetic carrier. Temperature-dependent susceptibility measurements differ from type 1 curves in only two sites, TP12 (type 2, Fig. 4c) and TP21 (type 3, Fig. 4d). TP12 shows a purely ferromagnetic behaviour with generation of new ferromagnetic sensu 
Table 1. AMS data for the sampling sites in the Castejón-Laspaúles basin

\begin{tabular}{|c|c|c|c|c|c|c|c|c|c|c|c|c|}
\hline Site & $\mathrm{N}$ & Lithology & $\mathrm{K}_{1}$ in situ & Conf. Ang. & $\mathrm{K}_{3}$ in situ & Conf. Ang. & $\operatorname{Km}\left(10^{-6}\right)$ & $\mathrm{e}\left(10^{-6}\right)$ & $\mathrm{Pj}$ & $\mathrm{e}$ & $\mathrm{T}$ & $\mathrm{e}$ \\
\hline TP12 & 15 & Pyroclastic & $063 / 49$ & $25 / 06$ & $243 / 42$ & $07 / 06$ & 1080 & 544 & 1.028 & 0.007 & 0.175 & 0.189 \\
\hline TP13 & 18 & Lava flow & $027 / 45$ & $26 / 09$ & $263 / 29$ & $16 / 09$ & 273 & 116 & 1.009 & 0.007 & 0.078 & 0.336 \\
\hline TP20 & 15 & Pyroclastic & $350 / 33$ & $08 / 05$ & $139 / 53$ & $57 / 06$ & 130 & 21.8 & 1.021 & 0.003 & -0.666 & 0.095 \\
\hline TP21 & 16 & Lava flow & $256 / 21$ & $17 / 09$ & $157 / 22$ & $40 / 16$ & 415 & 42.4 & 1.009 & 0.004 & -0.534 & 0.307 \\
\hline TP25 & 16 & Pyroclastic & $063 / 31$ & $15 / 07$ & $168 / 24$ & $11 / 06$ & 117 & 22.8 & 1.02 & 0.006 & 0.071 & 0.291 \\
\hline TP26 & 15 & Lava flow & $061 / 76$ & $09 / 04$ & $255 / 14$ & $09 / 04$ & 313 & 74.6 & 1.014 & 0.007 & 0.307 & 0.262 \\
\hline TP37 & 15 & Pyroclastic & $101 / 49$ & $21 / 07$ & $253 / 37$ & $19 / 07$ & 344 & 215 & 1.014 & 0.004 & 0.172 & 0.318 \\
\hline TP38 & 18 & Lava flow & $091 / 55$ & $14 / 07$ & $000 / 00$ & $20 / 08$ & 247 & 79.7 & 1.013 & 0.001 & -0.148 & 0.277 \\
\hline TP41 & 13 & Pyroclastic & $358 / 20$ & $19 / 07$ & $247 / 45$ & $22 / 09$ & 167 & 20.2 & 1.012 & 0.003 & -0.218 & 0.488 \\
\hline
\end{tabular}

$\mathrm{N}$ - number of samples; $\mathrm{K}_{1}$ and $\mathrm{K}_{3}$ - mean (trend/plunge) of the magnetic lineation and of the pole of the magnetic foliation (Jelinek, 1977) in geographic coordinates; Conf. Ang. - major and minor semi-axes of the $95 \%$ confidence ellipse (Jelinek, 1977); Km - magnitude of the magnetic susceptibility $\left(\cdot 10^{-6}\right) ; \mathrm{Pj}$ - corrected anisotropy degree (Jelinek, 1981); T - shape parameter (Jelinek, 1981); e - standard deviation.
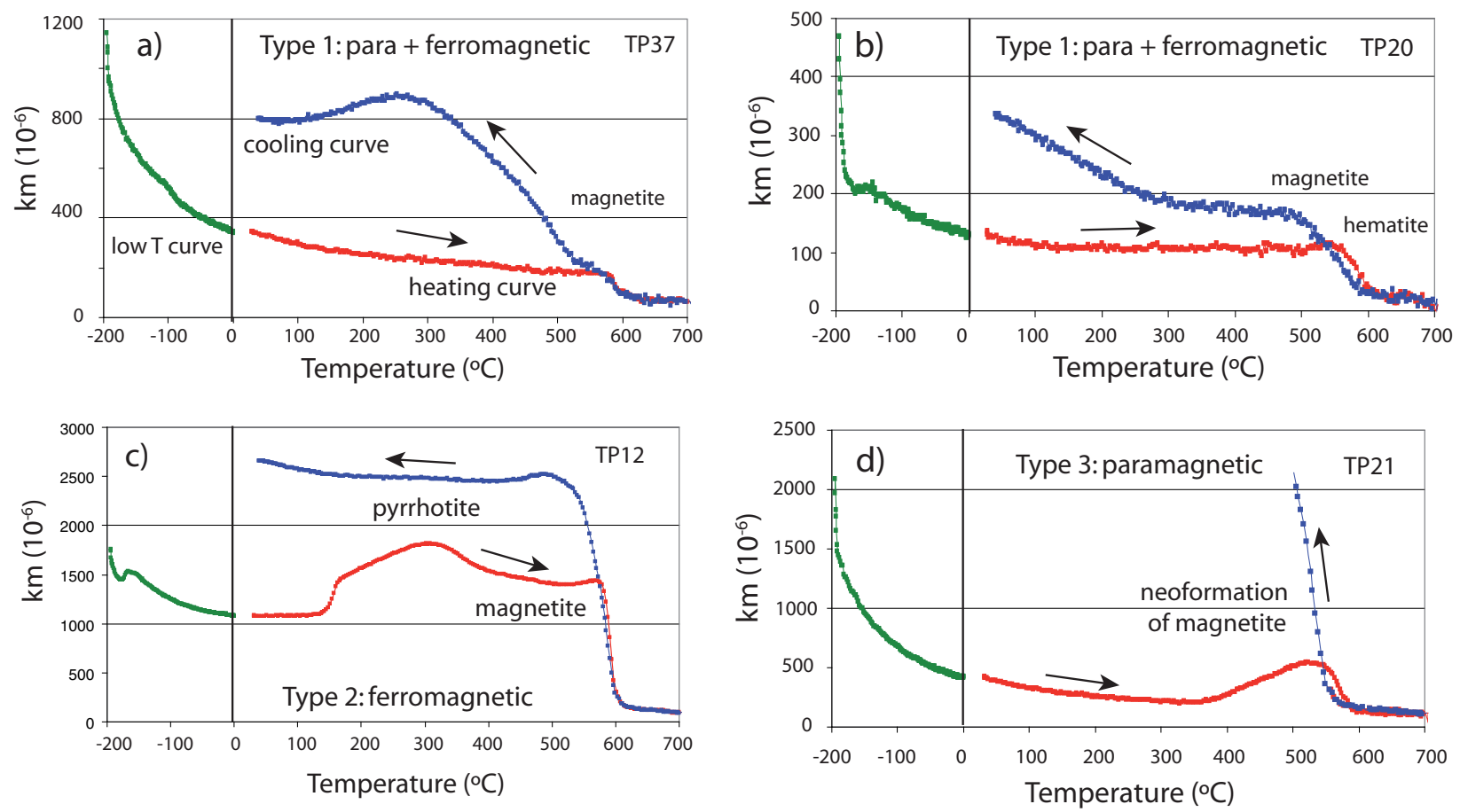

Figure 4. (Colour online) Temperature-dependent susceptibility curves $\left(-195\right.$ to $\left.700^{\circ} \mathrm{C}\right)$ of four representative samples. Curves indicate $(a, b)$ a mixed contribution of both paramagnetic and ferromagnetic carriers, (c) pure ferromagnetic behaviour and (d) prevalence of paramagnetic phases with neoformation of magnetite during heating.

lato phases while heating since magnetic susceptibility increases between 120 and $320^{\circ} \mathrm{C}$ and shows (i) a progressive drop between $320^{\circ} \mathrm{C}\left(T_{\mathrm{C}}\right.$ of ferromagnetic sensu lato iron sulphides) and $500^{\circ} \mathrm{C}$ and a (ii) drop at c. $580^{\circ} \mathrm{C}$ ( $T_{\mathrm{C}}$ of magnetite). On the other hand, TP21 shows a paramagnetic behaviour: the curve displays a concave-hyperbolic shape up to $360^{\circ} \mathrm{C}$, followed by an increase in the susceptibility between $360^{\circ}$ and $530^{\circ} \mathrm{C}$ and a drop between this temperature and $600{ }^{\circ} \mathrm{C}$. This peak is most probably related to the neoformation of magnetite during heating due to oxidation of paramagnetic minerals (iron-bearing silicates such as pyroxene, amphibole, chlorite, biotite and olivine; see thin-sections in Fig. 3). $\mathrm{K}-T$ curves are very sensitive to mineral reactions, which occur during the heating if magnetic phases become unstable (e.g. Deng et al. 2001). In all the studied samples, the $\mathrm{K}-T$ curves are irreversible, probably owing to the mineralogical alteration of the samples during heating and the creation of new magnetite (Fig. 4).

The low-temperature curves describe a hyperbolic decay of susceptibility with increasing temperatures (Fig. 4). TP20 (Fig. 4b) and TP12 (Fig. 4c) show a slight increase in susceptibility at $-165^{\circ} \mathrm{C}$, which could be related to a deviated Verwey transition of magnetite (Verwey, 1939).

IRM acquisition curves were performed in four samples and show two different behaviours: (i) in samples TP37 and TP13 (Fig. 5a, b) a low coercivity carrier prevails, probably magnetite (mean coercivity ranges between 20 and $45 \mathrm{mT}$ ), which contributes $80-90 \%$ to the IRM; (ii) in samples TP41 and TP20 a hard magnetic carrier dominates, probably haematite (mean coercivity ranges between 400 and $550 \mathrm{mT}$ ), which contributes 65 to $80 \%$ to the IRM and prevents the complete saturation of the curves at $2.5 \mathrm{~T}$ 

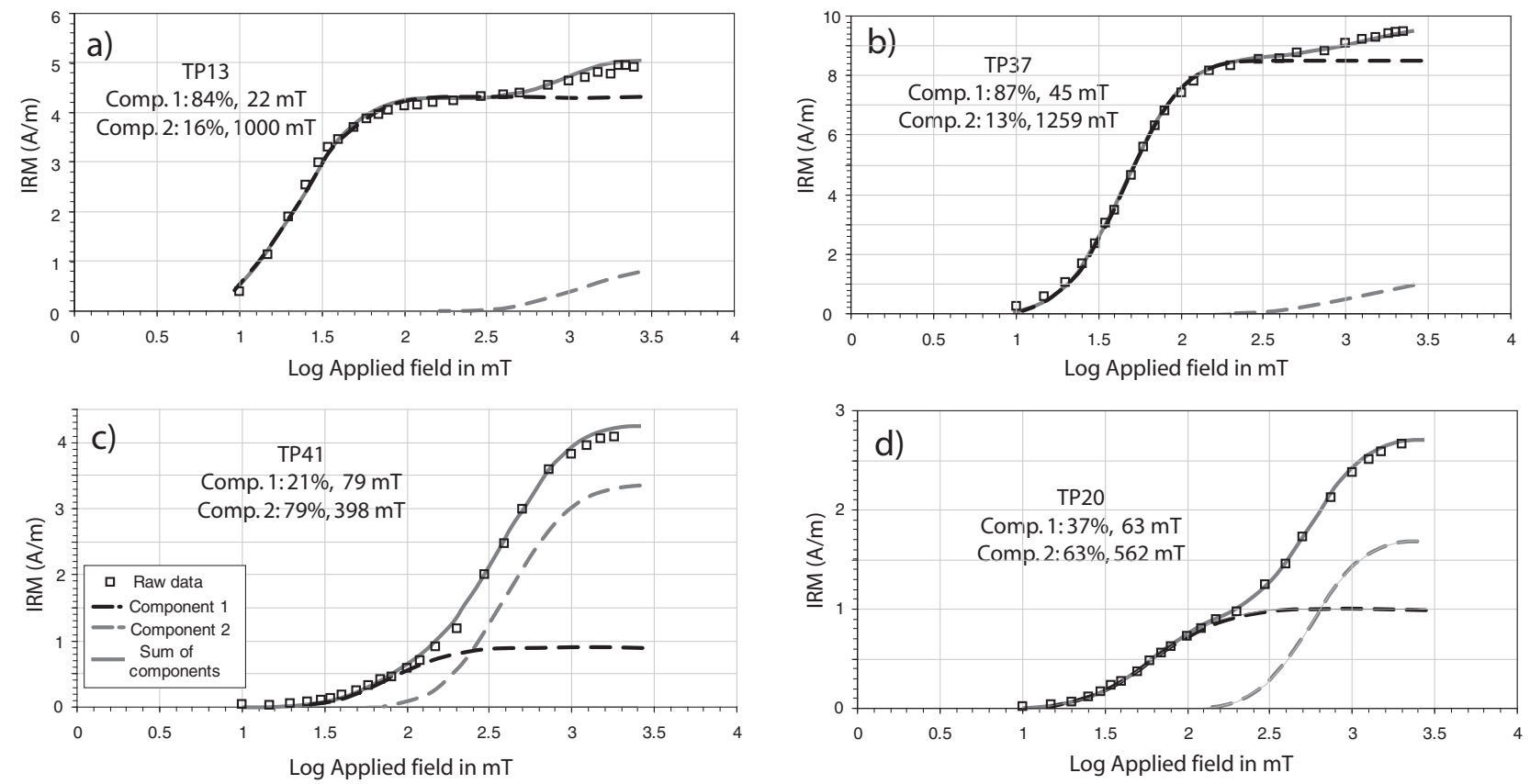

Figure 5. Analysis of the acquisition curves of the isothermal remanent magnetization (IRM) by means of the IRM-CLG 1.0 worksheet (Kruiver, Dekkers \& Heslop, 2001).
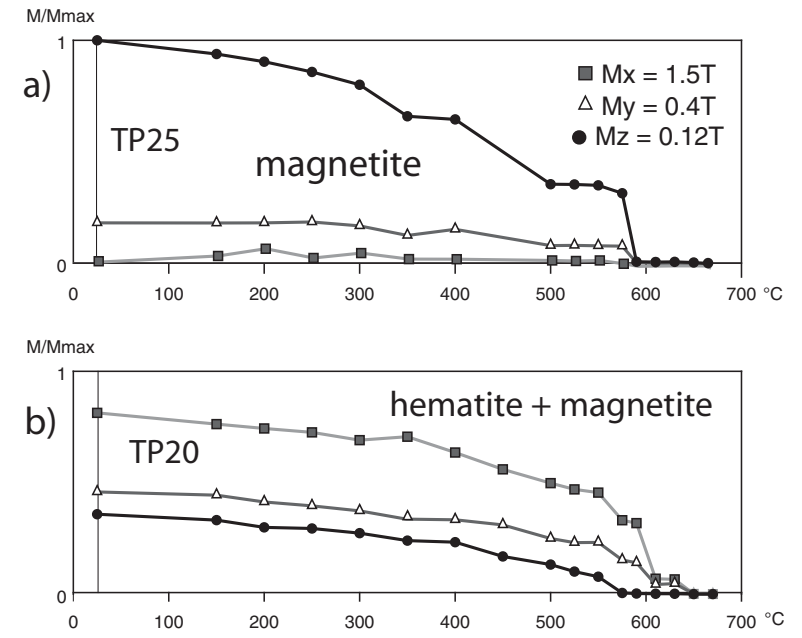

Figure 6. Stepwise thermal demagnetization of the composite IRM (Lowrie, 1990) in representative samples. Applied fields are $1.5,0.4$ and $0.12 \mathrm{~T}$.

(Fig. 5c, d). Thermal demagnetization of the composite IRM (Lowrie, 1990) is consistent with the IRM acquisition curves. It shows that magnetite is the main ferromagnetic carrier, as evidenced by a sharp decay in the soft $(120 \mathrm{mT})$ and intermediate $(400 \mathrm{mT})$ components between 500 and $590{ }^{\circ} \mathrm{C}$ (Fig. 6a). In two of the sites (site TP20 in Fig. 6b and site TP41), an abrupt decay of the intermediate $(400 \mathrm{mT})$ and hard axis $(1500 \mathrm{mT})$ around $630-650{ }^{\circ} \mathrm{C}$ indicates the occurrence of haematite in the samples (Fig. 6b), consistent with the $\mathrm{K}-$ $T$ curves that show a drop in susceptibility at around $680^{\circ} \mathrm{C}$.

These results are consistent with the palaeomagnetic data and indicate that mainly magnetite and in some samples haematite are the main carriers of the palaeomagnetic components reported in the volcanic and pyroclastic units of the Castejón-Laspaúles basin.

\section{5.c. Magnetic fabrics and image analysis}

The $\mathrm{Pj}-\mathrm{Km}$ (Fig. 7a) diagram shows (if site TP12 is not considered) a rough inverse correlation between them, with higher $\mathrm{Pj}$ values for the lower susceptibility samples. T-Km (Fig. 7b) and T-Pj (Fig. 7c) diagrams do not show a direct correlation between the shape parameter $(\mathrm{T})$ and the bulk susceptibility $(\mathrm{Km})$ or corrected anisotropy degree $(\mathrm{Pj})$. These results suggest that $\mathrm{Pj}$ values could be controlled by the magnetic mineralogy content in the samples, while the $\mathrm{T}$ parameter seems to be independent of the lithology or magnetic mineralogy and can be interpreted in terms of the internal structure of the lava flows and pyroclastic deposits. The corrected anisotropy degree is rather low for the whole dataset, ranging between 1.009 and 1.028, with an average value of 1.016 (Table 1; Fig. 7a, b). No significant differences are observed between the lava flows and the pyroclastic samples. The shape parameter $\mathrm{T}$ shows a wide variability, from oblate to strongly prolate ellipsoids (Table 1; Fig. 7b, c). Negative T values are dominant in sites located close to the boundary with the Variscan basement, in the lower stratigraphic units; oblate ellipsoids (positive $\mathrm{T}$ values) are mainly concentrated in the intermediate and upper stratigraphic units.

Concerning the orientation of the magnetic ellipsoid axes, sites can be grouped into two main types (AMS stereoplots are shown in Fig. 8). The first type (sites TP12, TP13, TP25, TP26 and TP37) shows an oblate 


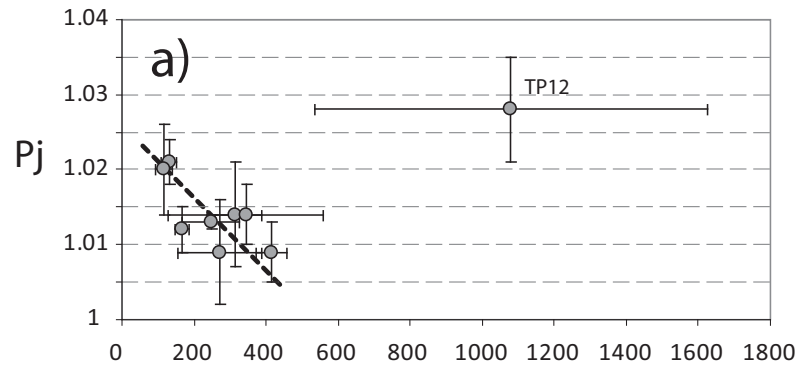

$\mathrm{Km}\left(\cdot 10^{-6}\right)$

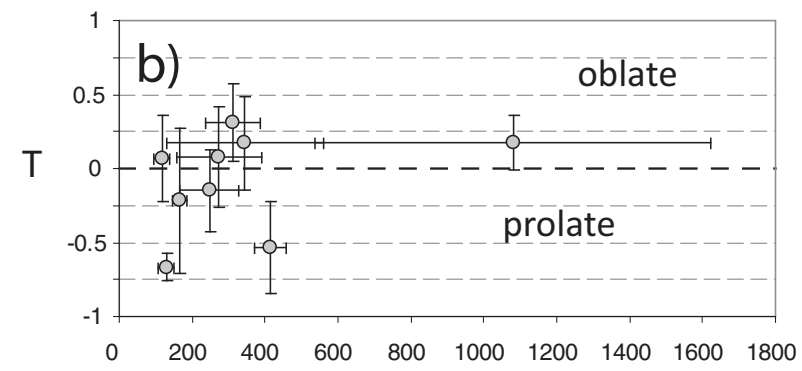

$\mathrm{Km}\left(\cdot 10^{-6}\right)$

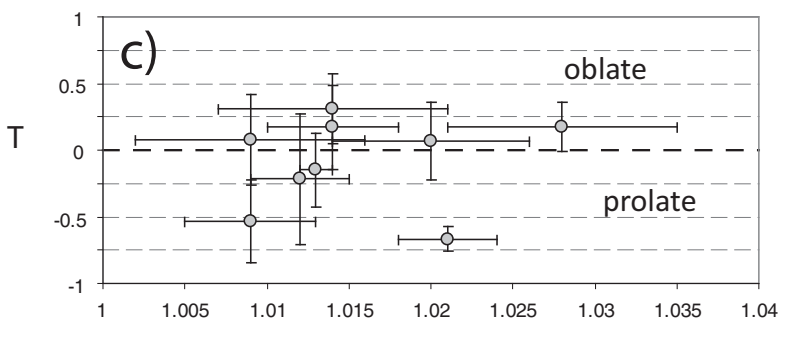

$\mathrm{Pj}$

Figure 7. (a) Corrected anisotropy degree (Pj) versus bulk magnetic susceptibility $(\mathrm{Km})$. (b) Shape parameter $(\mathrm{T})$ versus magnetic susceptibility $(\mathrm{Km})$. (c) Shape parameter $(\mathrm{T})$ versus the corrected anisotropy degree $(\mathrm{Pj})$. to triaxial magnetic ellipsoid: the minimum susceptibility axes are perpendicular to the bedding or flow plane (or oblique in TP37) and the maximum and intermediate axes are weakly to well grouped within these planes. The second type (sites TP20, TP38 and TP41) refers to prolate AMS ellipsoids: the maximum axes are clearly clustered within the bedding or flow plane, and $\mathrm{K}_{3}$ and $\mathrm{K}_{2}$ axes describe a girdle perpendicular to $\mathrm{K}_{1}$. A different type of AMS ellipsoid was obtained in site TP21 that shows a prolate fabric, with well-grouped $\mathrm{K}_{1}$ axes perpendicular to bedding, and $\mathrm{K}_{2}$ and $\mathrm{K}_{3}$ scattered within the girdle corresponding to the bedding or flow plane. Jelinek's major semi-axes for the $\mathrm{K}_{1} 95 \%$ confidence ellipse (Jelinek, 1977) are always smaller than $26^{\circ}$, and $67 \%$ of the sites show angles lower than $20^{\circ}$, indicating a well-defined magnetic lineation for the whole studied area (Table 1).

The bulk susceptibility at low temperature $(\sim 77 \mathrm{~K})$ is $1.7,1.9,2.1$ and 2.9 times the bulk susceptibility at room temperature for the four selected sites (Fig. 9). These ratios (lower than the 3.8 expected for pure paramagnetic samples but higher than 1) could indicate a mixed contribution of ferromagnetic and paramagnetic phases to the AMS that is consistent with the results obtained in the temperature-dependent magnetic susceptibility curves. The orientation of the $\mathrm{K}_{1}, \mathrm{~K}_{2}$ and $\mathrm{K}_{3}$ axes at low temperature (enhanced paramagnetic fabrics) overlaps the results of the AMS at room temperature (Fig. 9). Only in site TP26, slightly different results were obtained for the orientation of the AMS at room and at low temperatures (Fig. 9), suggesting a composite fabric: $\mathrm{K}_{1}$ and $\mathrm{K}_{2}$ axes are well grouped at room temperature, but at low temperature $\mathrm{K}_{1}$ shows a higher dispersion within the bedding plane and its average value is at an angle of $\sim 35^{\circ}$ with regards to the mean $\mathrm{K}_{1}$ at room temperature.

The reliability of the AMS results was tested by means of image analysis. Results (Fig. 10) show that,

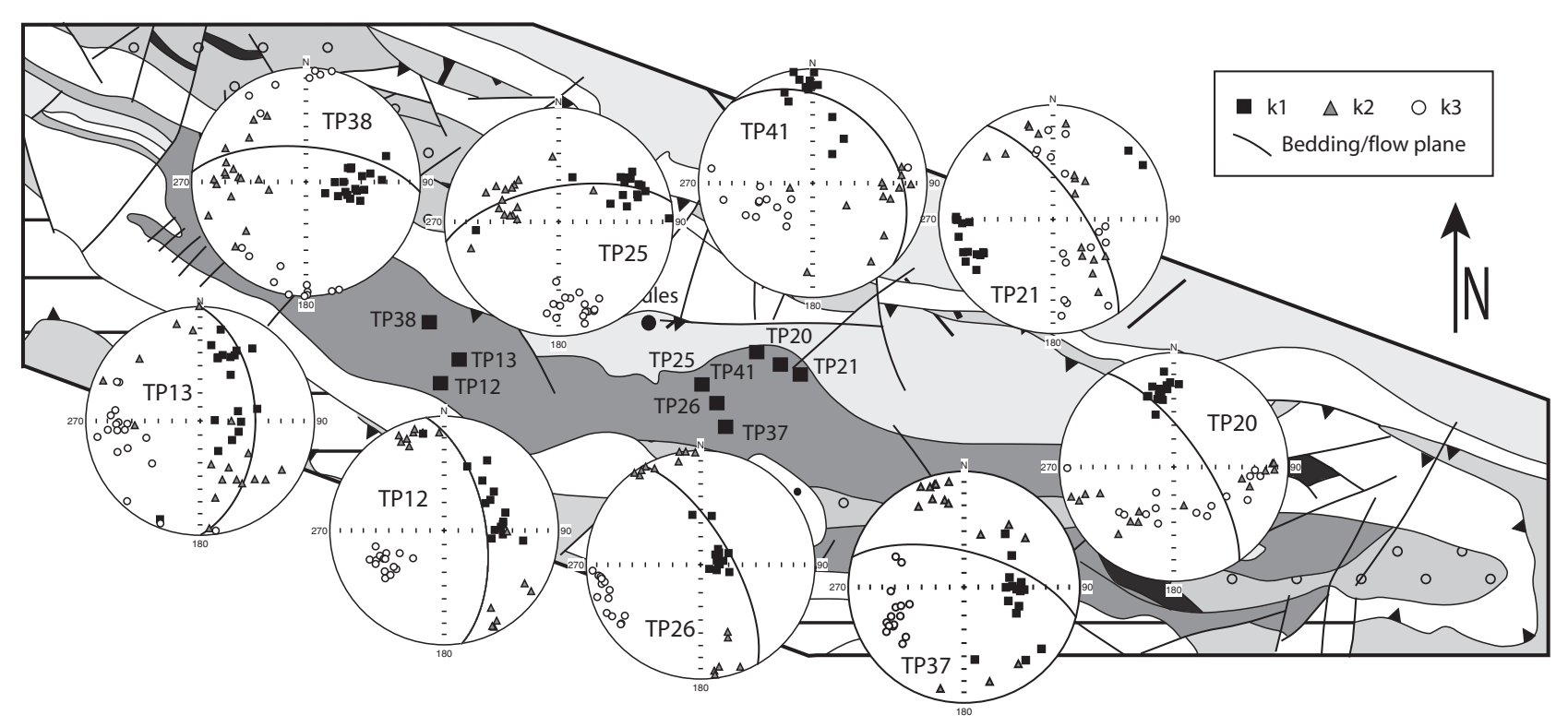

Figure 8. AMS ellipsoids obtained for each sampling site. The projection of the bedding/flow plane is shown. 

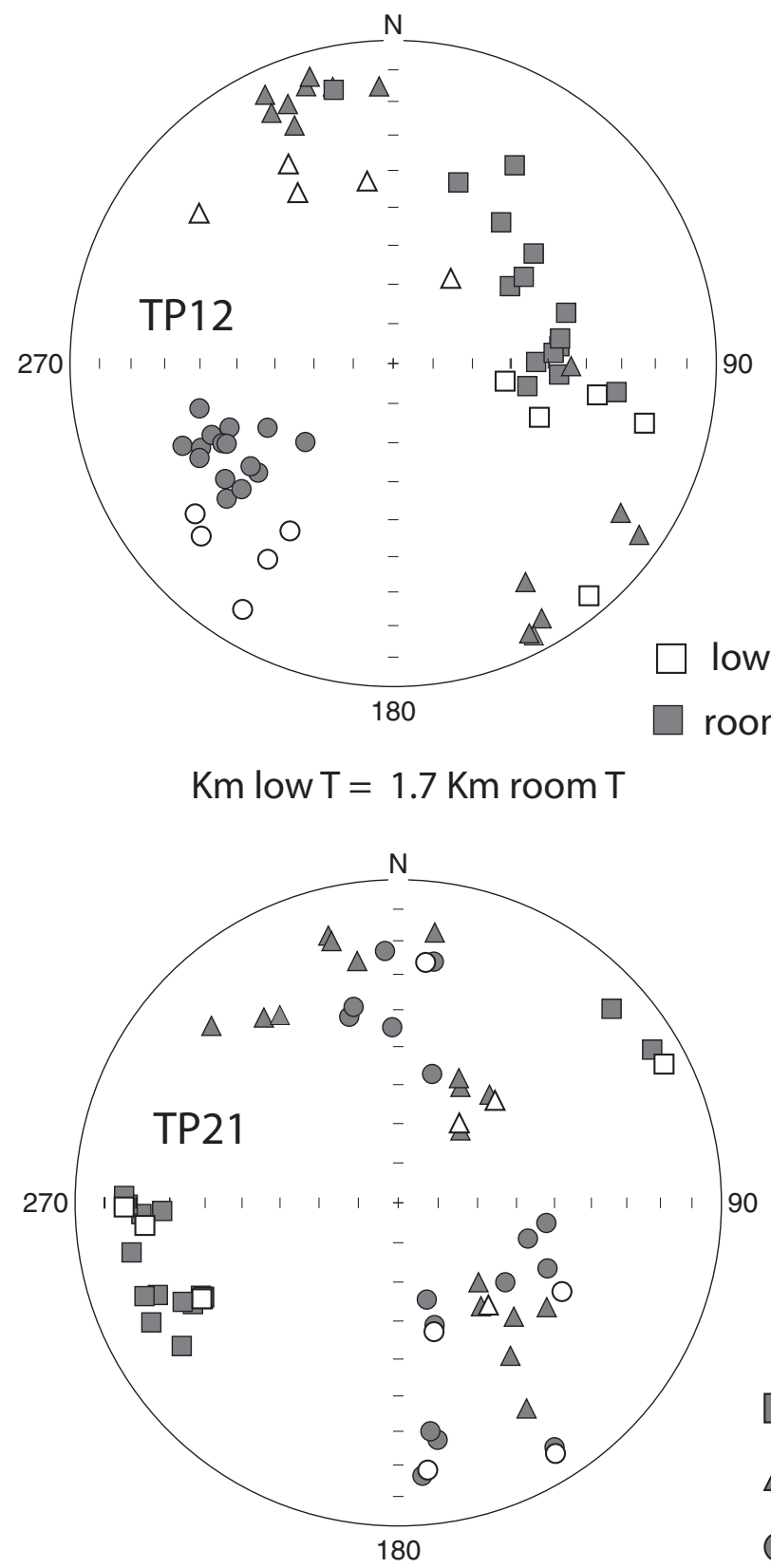

$\mathrm{Km}$ low $\mathrm{T}=2.9 \mathrm{Km}$ room $\mathrm{T}$
$\mathrm{Km}$ low $\mathrm{T}=1.7 \mathrm{Km}$ room $\mathrm{T}$

$\square \mathrm{K} 1$
$\triangle \mathrm{K} 2$
$\mathrm{~K} 3$

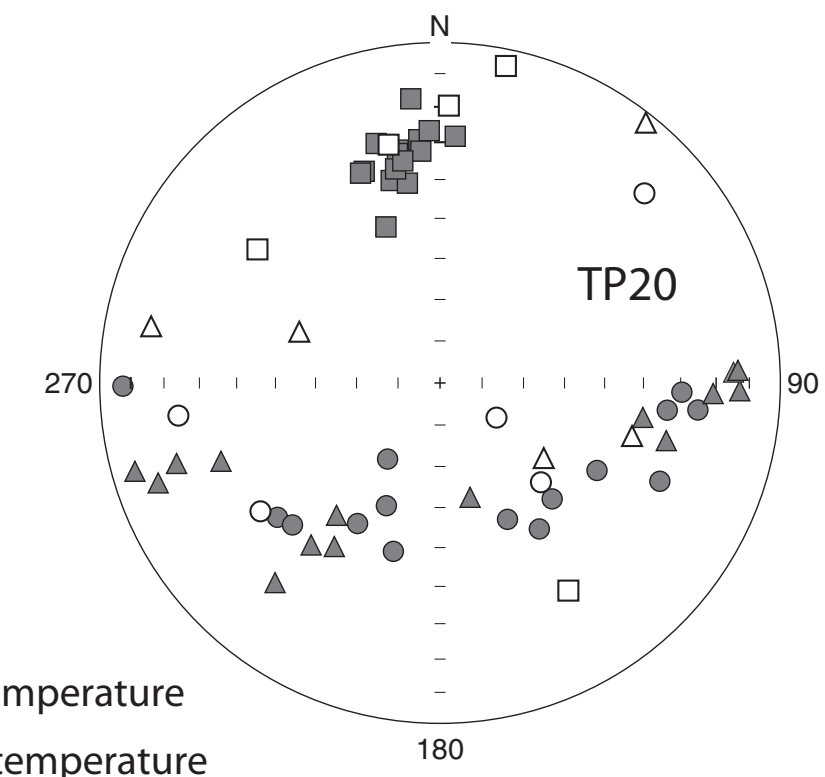

$\mathrm{Km}$ low $\mathrm{T}=1.9 \mathrm{Km}$ room $\mathrm{T}$

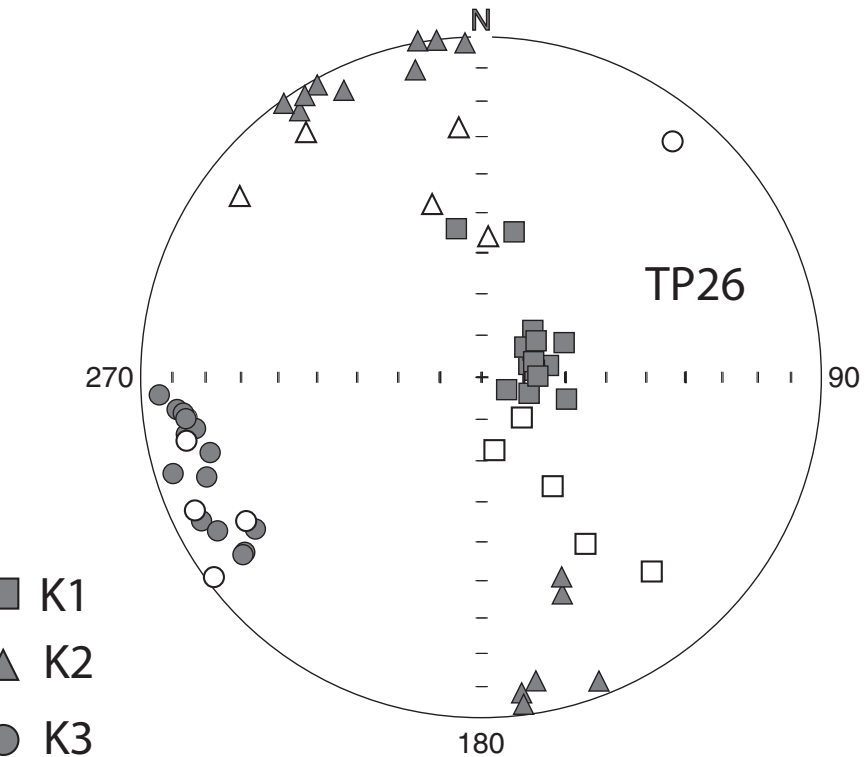

$\mathrm{Km}$ low $\mathrm{T}=2.1 \mathrm{Km}$ room $\mathrm{T}$

Figure 9. Stereoplot of AMS at room (grey symbols) and at low temperature (white symbols). See text for explanation.

in all the analysed samples, the AMS approximates the shape preferred orientation (SPO) measured for fragments and/or crystals. Therefore, the magnetic foliation plane can be relied upon as the bedding or flow plane, even in sites where this plane was not easily defined at the outcrop scale. The aspect ratio of a particle's fitted ellipse is always lower in the thin-sections parallel to the magnetic foliation and higher in the thin-sections perpendicular to it: eccentricity is either higher in the thin-section containing the $\mathrm{K}_{1}$ axis (Fig. 10a, TP13) or similar for both sections containing the $\mathrm{K}_{1}$ and $\mathrm{K}_{2}$ axes (Fig. 10a, TP25). In some of the samples, ImageJ reveals the existence of two preferred orientation maxima at lower angles $\left(\sim 20^{\circ}\right)$, probably coinciding with one population of fragments whose longer axis is contained within the bedding or flow plane and a secondary population of imbricated particles (Fig. 10b, c, site TP25; for a discussion of this type of results see Oliva-Urcia et al. 2012a).

\section{5.d. Palaeomagnetism}

Stepwise thermal or AF demagnetization was performed in nine sampling sites (Table 2). AF demagnetization was successful (the remanent magnetization at $100-120 \mathrm{mT}$ is lower than $20 \%$ of the NRM) in pilot samples from four of the sites. Mean destructive fields vary in the different sites, and even among samples from the same site (Table 2): $32 \%$ of the samples demagnetized by AF showed remanent 
a)

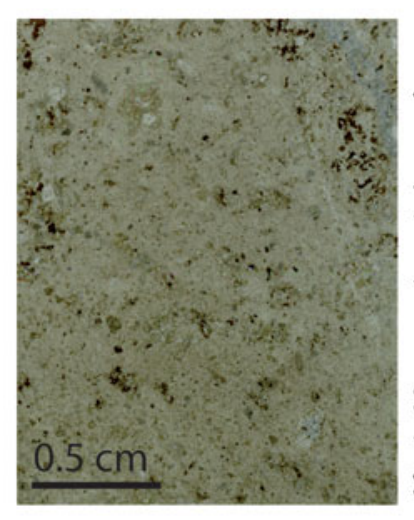

TP13-1

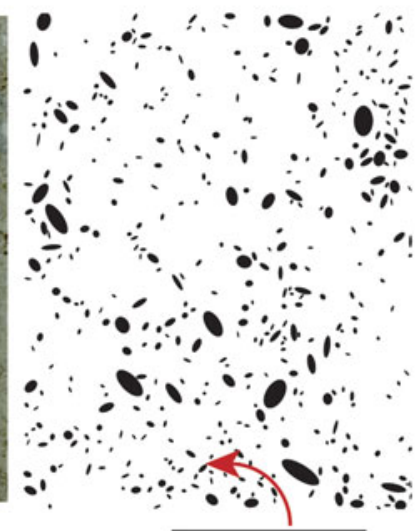

b)

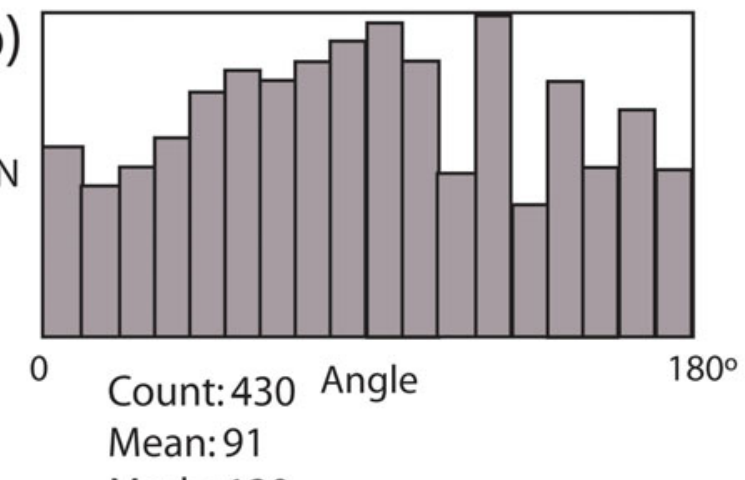

Mode: 120
TP25-1
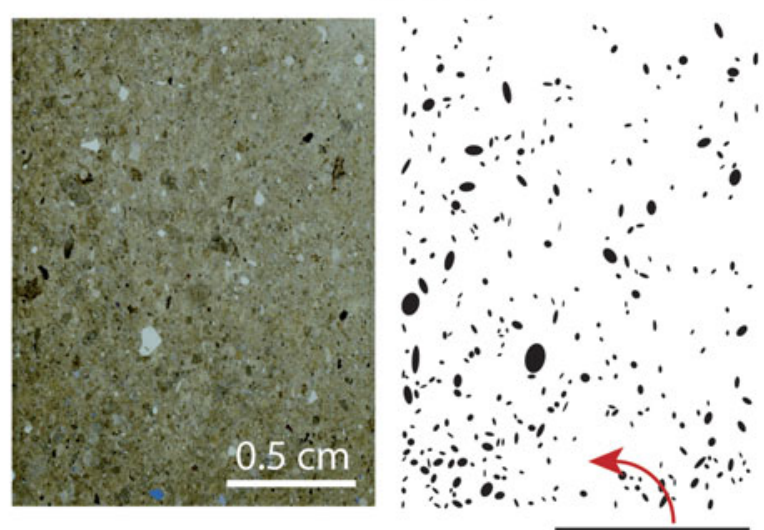

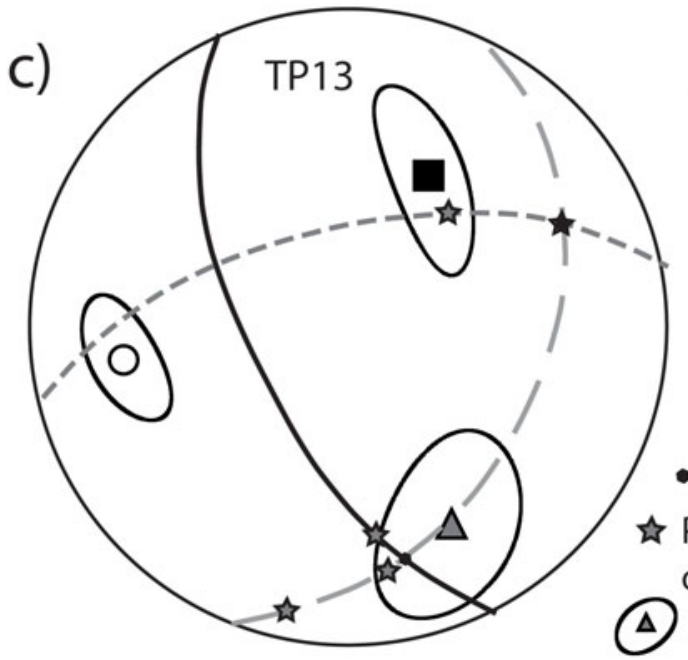

(4)

$\begin{gathered}\text { AR (aspect ratio of } \\ \text { particle's fitted ellipse) }\end{gathered}=\frac{\text { Major axis }}{\text { Minor axis }}$
AR (plane K1-K3) $=1.92$
AR (plane K2-K3) $=1.89$
AR (plane K1-K2) $=1.79$
Plane K2-K3

Plane K1-K3 Plane K1-K2

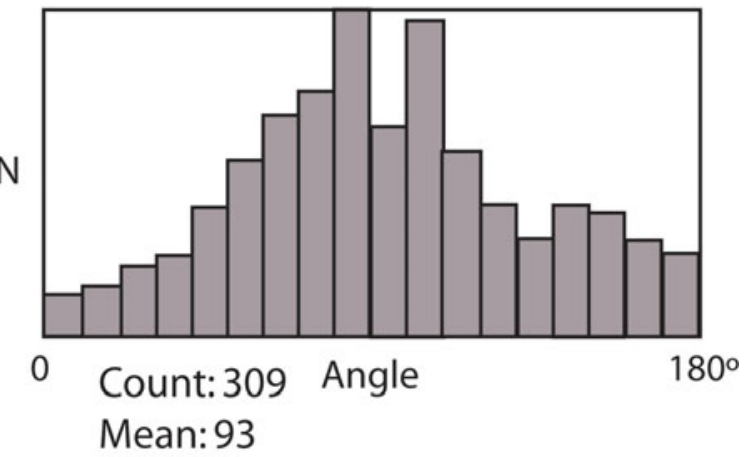

Mode: 80
- Line of reference

Preferred orientation of the ellipses (ImageJ) AMS (mean direction)

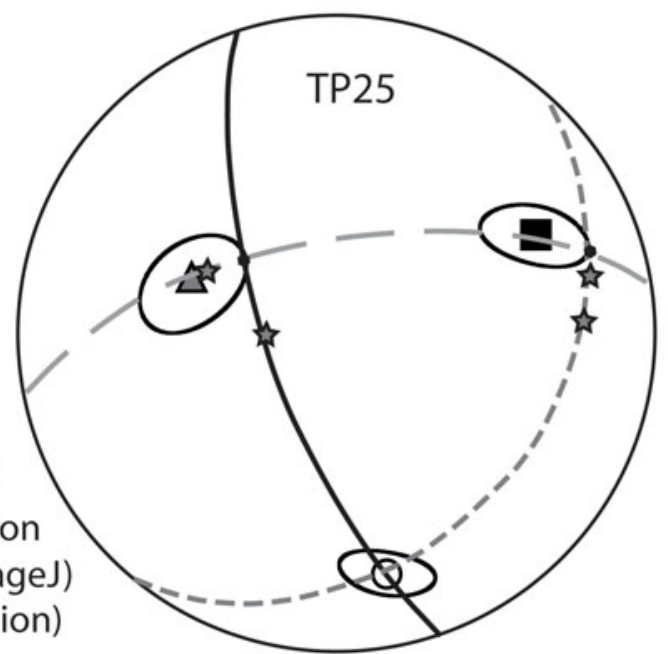

AR (plane K1-K3) $=2.01$

AR (plane $K 2-K 3)=2.06$

AR (plane K1-K2) $=1.92$

Figure 10. (Colour online) Image analysis results for the sections containing K1 and K3 axes (perpendicular to magnetic foliation and containing the magnetic lineation) in samples TP13 (to the left) and TP25 (to the right). (a) Original thin-section and after fitting the particle's shape to an ellipse by means of the ImageJ free software. (b) ImageJ results for the shape preferred orientation of the obtained ellipses. The histogram represents the number of ellipses versus the angle between their long axes and the reference line plotted in (a) (measured anticlockwise). (c) Comparison between the orientation of the AMS axis and the preferred shape orientation obtained by ImageJ in three perpendicular sections. AR is the aspect ratio of the ellipses fitted in each section (a higher value indicates a higher eccentricity).

magnetizations lower than $30 \%$ of the NRM under fields of $40 \mathrm{mT}$ and $68 \%$ under fields of $70 \mathrm{mT}$ (Fig. 11a). In samples that were thermally demagnetized (because AF was unable to fully destroy the remanence), two main temperature-related decays of mag- netization could be distinguished (Fig. 11b): a lower temperature decay, between $550^{\circ}$ and $630^{\circ} \mathrm{C}$, corresponding to magnetite/maghaemite $(\mathrm{C} 1 \mathrm{in}$ Fig. $11 \mathrm{c})$, and a higher temperature decay, between $620^{\circ}$ and $680^{\circ} \mathrm{C}$, corresponding to haematite (C2 in Fig. 11c). In sites 
Table 2. Palaeomagnetic data for the sampling sites in the Castejón-Laspaúles basin

\begin{tabular}{|c|c|c|c|c|c|c|c|c|c|c|c|c|}
\hline Site & $\begin{array}{l}\text { NRM } \\
(\mathrm{A} / \mathrm{m})\end{array}$ & $\mathrm{e}$ & $\mathrm{C}$ & Method & $n / N$ & $\begin{array}{c}\mathrm{D} \\
\text { (BTC) }\end{array}$ & $\begin{array}{c}\text { I } \\
\text { (BTC) }\end{array}$ & $\mathrm{DF}(\mathrm{mT})$ & $\begin{array}{l}\text { Tunb } \\
\left({ }^{\circ} \mathrm{C}\right)\end{array}$ & $\alpha 95$ & $\mathrm{k}$ & So \\
\hline TP12 & 0.26 & 0.17 & $\mathrm{C} 1$ & TD & $8 / 8$ & 4.5 & 65 & & $590-610$ & 6 & 100 & 171,60 E (o) \\
\hline TP13 & 0.0504 & 0.093 & $\mathrm{C} 1$ & $\mathrm{AF}+\mathrm{TD}$ & $6 / 9$ & 256 & 84 & $30-80$ & $575-620$ & 8 & 60 & $180,50 \mathrm{E}(\mathrm{o})$ \\
\hline \multirow[t]{2}{*}{ ТР20 } & 0.005 & 0.0047 & $\mathrm{C} 1$ & $\mathrm{TD}$ & $5 / 8$ & 20 & 39 & & $590-630$ & 8 & 100 & $145,70 \mathrm{NE}(\mathrm{o})$ \\
\hline & & & $\mathrm{C} 2$ & & $5 / 8$ & 18 & 37 & & $665-680$ & 11 & 53 & \\
\hline TP21 & 0.00032 & 0.00026 & $\mathrm{C} 2$ & TD & 9/9 & 24 & 43 & & $>550$ & 7 & 59 & $145,70 \mathrm{NE}$ (o) \\
\hline TP25 & 0.00039 & 0.00024 & $\mathrm{C} 1$ & $\mathrm{AF}$ & $7 / 9$ & 339 & 65 & $60-90$ & $>500$ & 12 & 27 & $085,60 \mathrm{~N}(\mathrm{o})$ \\
\hline ТР26 & 0.0037 & 0.0015 & $\mathrm{C} 1$ & $\mathrm{AF}$ & $8 / 8$ & 25 & 53 & $20-35$ & 550 & 8 & 52 & $150,68 \mathrm{~N}(\mathrm{o})$ \\
\hline \multirow[t]{2}{*}{ TP37-f } & 0.182 & 0.1161 & $\mathrm{C} 1$ & TD & $2 / 6$ & random & & & $550-600$ & & & $105,65 \mathrm{~N}(\mathrm{o})$ \\
\hline & & & $\mathrm{C} 2$ & & $4 / 6$ & random & & & $620-650$ & & & \\
\hline TP37-m & 0.0325 & 0.0704 & $\mathrm{C} 1$ & $\mathrm{AF}+\mathrm{TD}$ & $5 / 8$ & 42 & 73 & $55-65$ & 600 & 24 & 11 & $105,65 \mathrm{~N}(\mathrm{o})$ \\
\hline TP38 & 0.0026 & 0.0019 & $\mathrm{C} 1$ & $\mathrm{TD}$ & $8 / 9$ & 217 & 74 & & $610-660$ & & 4 & $095,65 \mathrm{~N}(\mathrm{o})$ \\
\hline \multirow{2}{*}{ TP41 } & 0.00225 & 0.0014 & $\mathrm{C} 1$ & TD & $6 / 9$ & 19 & 33 & & $500-575$ & 19 & 13 & $135,30 \mathrm{~N}(\mathrm{o})$ \\
\hline & & & $\mathrm{C} 2$ & & $8 / 9$ & 2 & 32 & & $600-620$ & 11 & 28 & \\
\hline
\end{tabular}

Site TP37 shows the conglomerate test (TP37-m refers to the matrix and TP37-f to the lithic fragments). NRM - natural remanent magnetization (in Ampere/metre); $\mathrm{e}$ - standard deviation of NRM; $\mathrm{C}$ - palaeomagnetic component ( $\mathrm{C} 1$ for magnetite/maghaemite and $\mathrm{C} 2$ for haematite); demagnetization method ( $\mathrm{TD}$ - thermal demagnetization; $\mathrm{AF}$ - alternating field demagnetization); $\mathrm{n} / \mathrm{N}$ - number of samples used to calculate the mean from the total number of standard samples; D (BTC) and I (BTC) - declination and inclination before tectonic correction; DF - mean destructive field (the remanent magnetization is lower than $30 \%$ of the NRM); Tunb - maximum unblocking temperature; $\alpha 95$ and $\mathrm{k}$ are the statistical parameters of a Fisherian distribution; So - bedding plane (strike and dip; o for overturned beds).

a) TP25-18. Alternating field demagnetization

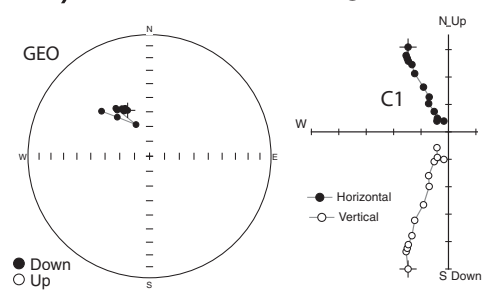

b) TP20-16. Thermal demagnetization

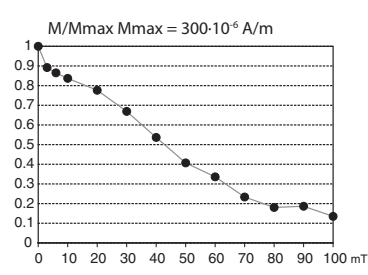
Applied field (mT)
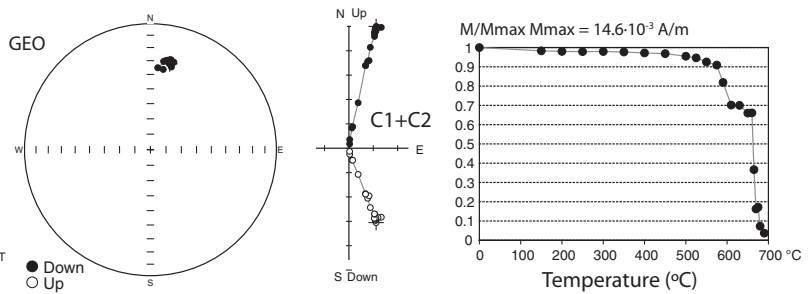

c)
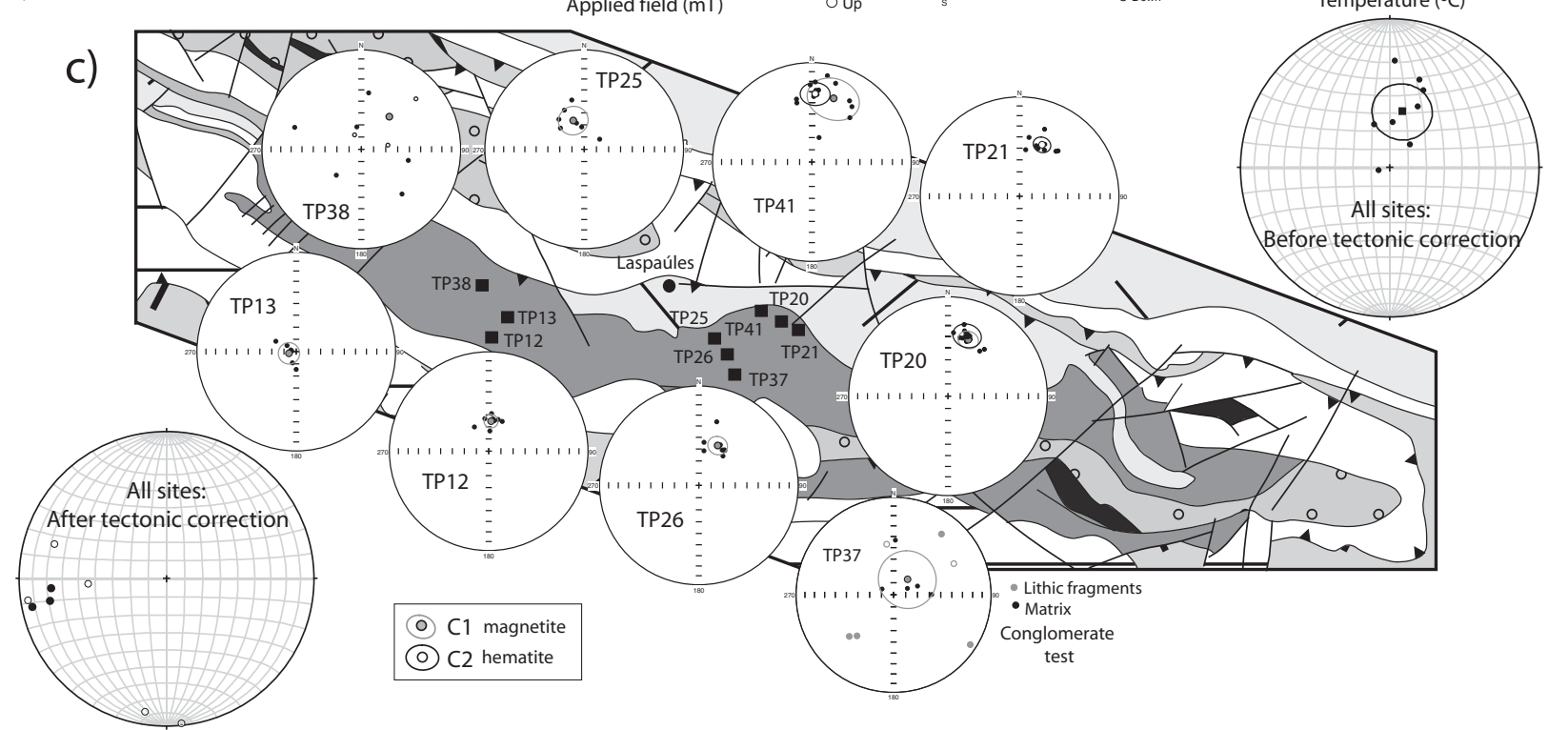
Temperature $\left({ }^{\circ} \mathrm{C}\right)$

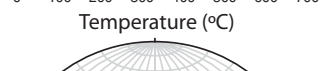

Figure 11. Results of the palaeomagnetic study. Orthogonal diagrams, decay of the magnetization and lower hemisphere equal-area stereographic projections during stepwise $\mathrm{AF}$ (a) or thermal (b) demagnetization. (c) Lower hemisphere stereoplots showing the samples' components (calculated using the PCA method) and the site means (Fisher statistics; Fisher, 1953). The lateral stereoplots include the site means for the whole dataset before and after simple-bedding correction. In sites were both, components $\mathrm{C} 1$ and $\mathrm{C} 2$ were defined, the one showing the smaller $\alpha 95$ was chosen.

where both minerals are present, no significant differences in the orientation of the components carried by them were observed (Table 2; Fig. 11b, c).

The demagnetization of the whole dataset reveals the presence of one stable, well-defined component in all but one of the sites (TP38) (Table 2). This component is
$\mathrm{N}$-trending and shows variable inclinations, from subhorizontal to subvertical. It displays a normal polarity direction in geographic coordinates and is scattered along a NNE-SSW-striking plane, perpendicular to the trend of the fold axes. This distribution strongly suggests a pre- or syn-folding acquisition (Table 2; 
Fig. 11c). The average orientation for this component (computed from the average values of each site) is Dec., Inc. $=012,59\left(\alpha 95=16^{\circ}, \mathrm{k}=11\right)$ (Fig. 11c). After the simple bedding-plane restoration, this component is subhorizontal or shallowly plunging and can be subdivided into two groups (Fig. 11c): (1) two sites show S-trending and subhorizontal components and (2) 6 sites display W-trending components with shallow to intermediate inclinations. The distribution of this component after tectonic correction is strongly conditioned by the strike of the bedding or flow plane: $\mathrm{W}$-trending components result from the simple restoration of N-S or NW-SE-striking bedding/flow planes and S-trending components from the restoration of E-W-striking bedding/flow planes.

In site TP37 it was possible to perform a conglomerate test (Watson, 1956), which indicates that the palaeomagnetic component of the clasts (centimetric lithic fragments in the ignimbrite) has a random distribution (Fig. 11c) whereas that of the matrix shows a better grouped distribution. Samples containing both matrix and clasts also showed a random distribution and have been disregarded in Figure 11c. The result of the conglomerate test suggests a primary origin for the calculated palaeomagnetic components.

\section{Discussion}

6.a. Contribution of palaeomagnetic data to the restoration of bedding and the determination of vertical axis rotations

Two main arguments suggest that the palaeomagnetic component defined in the study area was acquired early with regards to Alpine compressional deformation: (i) the distribution of the components defined for the whole dataset (Fig. 11c) shows they are folded following the Alpine structure, and therefore, its acquisition pre-dates, or is early, with regards to the compressional stages and (ii) the conglomerate test is positive, indicating that the component was acquired very early in the history of the deposit and probably has a primary origin. After simple-bedding restoration (Figs 11c, 12) the palaeomagnetic components diverge into two different groups separated an angle of $\sim 90^{\circ}$ : sites where the bedding or flow plane was strongly oblique to the Alpine structures (N-S- to NW-SE-striking planes in sites TP12, TP13, TP20, TP21, TP26 and TP41) show a W-trending component after bedding restoration, and sites where the bedding/flow planes strike sub-parallel to the Alpine structure (E-W- to WNWESE-striking planes in sites TP25 and TP37) show a S-trending component. There is a clear influence of the strike of bedding on the restoration that cannot be justified in terms of vertical axis rotations (VARs) if palaeomagnetic studies in the adjacent Triassic red beds are taken into account (Bates, 1989; Izquierdo-Llavall et al. 2012a). Disregarding the possibility of relative VARs of almost $90^{\circ}$ between the different sites, the existence of bedding/flow planes striking oblique to the main Pyrenean direction can be interpreted as due to a pre-compressional tilting of the beds. In this situation, a two-step bedding correction can be applied (Fig. 12; Table 3) according to the most plausible sequence of events: (1) restoration of the compressional structure and (2) tilt correction of the bedding/flow plane resulting after the first step. For the first step we used the orientation of bedding planes measured in the Lower Triassic red beds (Buntsandstein unit) that overlie the volcanic units sampled in the different sectors of the basin (see structural data in Fig. $1 \mathrm{~b}$ and Table 3). The strike of bedding in the Lower Triassic units is subparallel to the fold axes and to the strike of thrusts, and its dip reflects the superimposition of horizontal axis rotations related to two coaxial compressional stages: the folding of the beds in hangingwall, thrustrelated anticlines, and its foreland-wards tilting due to the emplacement of underlying basement thrusts (see cross-section in Fig. 1d). The surface obtained after this first step represents the orientation of the beds prior to the Alpine compression (Fig. 12a), and indicates that there was a dominant intermediate-to-steep westward tilting of the beds pre-dating Pyrenean folding (Table 3). After the two-step bedding correction, the palaeomagnetic components are well grouped and show a subhorizontal, SSW-trending direction (Dec., Inc. $\left.=193,-05 ; \alpha 95=18^{\circ}, \mathrm{k}=0.9\right)$. When compared to the Stephanian reference (Dec., Inc. $=336,-06$; $\alpha 95=12.5^{\circ}$; computed for a central position of the basin from three references in Van der Voo, 1969, compiled by Osete \& Palencia, 2006), they show similar inclination values but are clockwise rotated an average of $+37^{\circ}$ (Fig. 12b). The error in the rotation $(\alpha 95$ of the average component calculated from the new dataset $+\alpha 95$ of the Stephanian reference) is big $\left( \pm 32^{\circ}\right)$ but the inferred mean clockwise rotation is statistically distinguishable from the Stephanian reference. Similar rotation values have been obtained in the overlying Triassic red beds (Izquierdo-Llavall et al. 2012a) with regards to the Permian-Triassic reference for this sector of the Pyrenees (Dec., Inc. $=345,14 ; \alpha 95=5.8^{\circ}, \mathrm{k}=138.3$; from data by Parés, van der Voo \& Stamatakos, 1996; Schott \& Perés, 1987 and Osete et al. 1997, compiled in Osete \& Palencia, 2006). In all sites, a reverse polarity component is obtained (for both, northern and southern hemisphere positions), consistent with the Kiaman reverse superchron (312-262 Ma) (Molina-Garza, Geissman \& van der Voo, 1989).

\section{6.b. Interpretation of magnetic fabrics}

The stereoplots in Figure 13a show the whole dataset of in situ magnetic fabrics. $\mathrm{K}_{1}$ axes are distributed within a girdle $(170,60 \mathrm{E})$ that is approximately perpendicular to the regional fold axis and contains two maxima: a N-trending, shallowly plunging maximum and an E-trending, steeply plunging maximum. $\mathrm{K}_{3}$ describes a principal, W-trending and intermediately plunging maximum and a secondary, S-trending, shallowly plunging maximum. $\mathrm{K}_{3}$ axes are mostly subperpendicular to the bedding or flow planes while $\mathrm{K}_{1}$ 

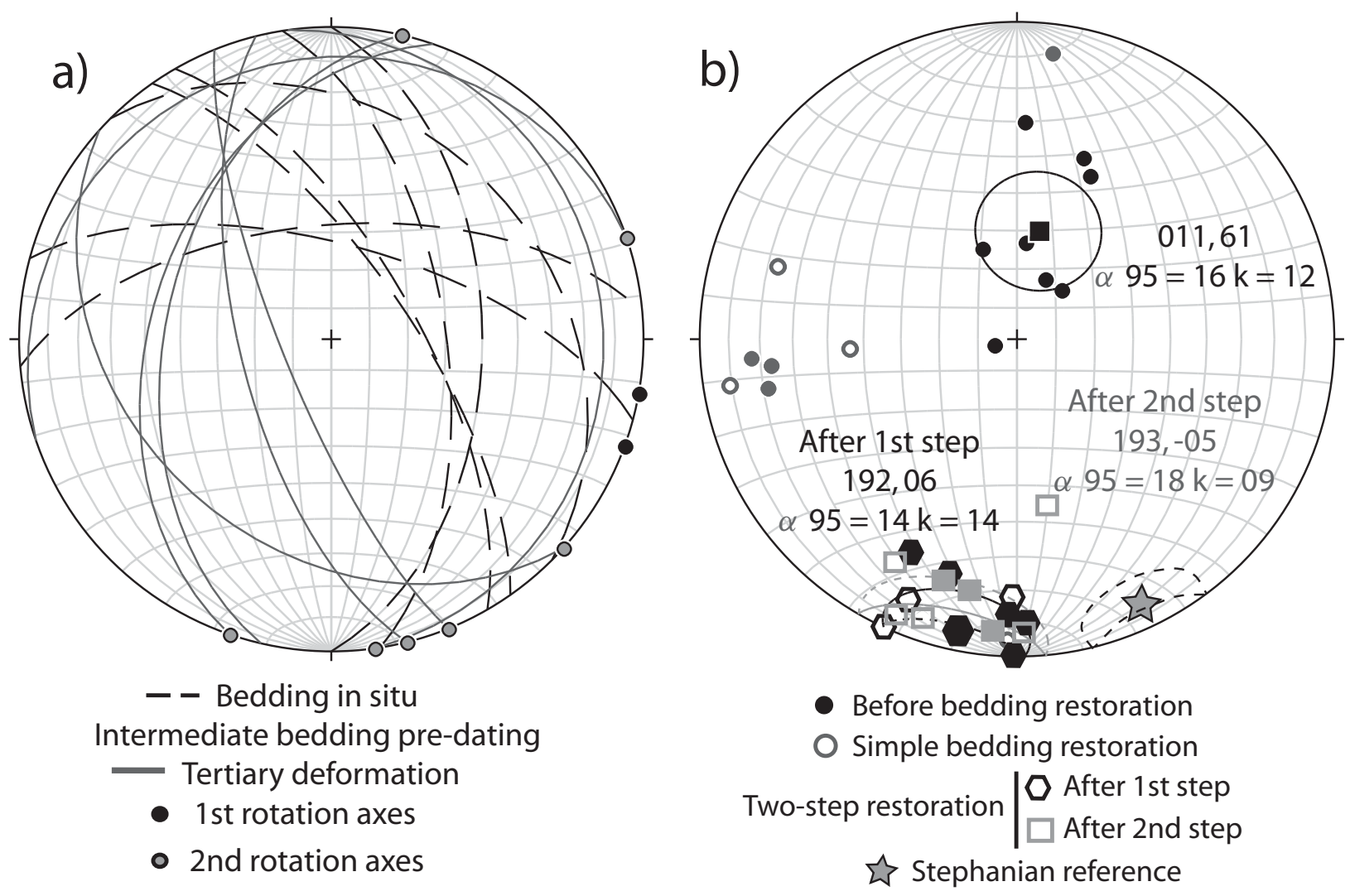

Figure 12. (a) Stereoplot showing bedding or flow planes before tectonic correction and after restoration of Alpine folding. (b) Orientation of the palaeomagnetic components before and after tectonic correction (using the two-step and the simple-bedding restoration). After the first step, a reverse polarity, southern hemisphere component is dominant and $\alpha 95$ is $14^{\circ}$. After the second step $\alpha 95$ is $18^{\circ}$; some sites keep a reverse polarity, southern hemisphere component while others show a reverse polarity, northern hemisphere component. The average component is clockwise rotated with regards to the Stephanian reference: Dec., Inc. $=336,-06$; $\alpha 95=14^{\circ}$ (calculated from three references in Van der Voo (1969) for a central position of the basin: latitude of $42^{\circ} 28^{\prime} \mathrm{N}$ and longitude of $\left.0^{\circ} 36^{\prime} \mathrm{E}\right)$.

Table 3. Simple and two-step bedding restoration

2-step So correction

\begin{tabular}{|c|c|c|c|c|c|c|c|c|c|}
\hline Site & $\mathrm{C}$ & $\begin{array}{c}\mathrm{D}, \mathrm{I} \\
\text { (BTC) }\end{array}$ & So & $\begin{array}{l}\text { Simple So } \\
\text { correction. D, I } \\
\text { (ATC) }\end{array}$ & $\begin{array}{c}\text { 1st rotation } \\
\text { axes }\end{array}$ & $\begin{array}{l}\text { intermediate } \\
\text { So }\end{array}$ & $\begin{array}{c}\mathrm{D}, \mathrm{I}(\mathrm{after} \\
\text { 1st rotation) }\end{array}$ & $\begin{array}{l}\text { 2nd rotation } \\
\text { axes }\end{array}$ & $\begin{array}{c}\mathrm{D}, \mathrm{I} \text { (after } \\
\text { 2nd rotation) }\end{array}$ \\
\hline TP12 & $\mathrm{C} 1$ & 005,65 & 171,60 E (o) & $287,-22$ & 110,$00 ;-88^{\circ}$ & $166,66 \mathrm{~W}$ & 207,26 & 166,$00 ;-66$ & $209,-21$ \\
\hline TP13 & $\mathrm{C} 1$ & 256,84 & $180,50 \mathrm{E}(\mathrm{o})$ & $267,-46$ & 110,$00 ;-88^{\circ}$ & $158,77 \mathrm{~W}$ & $205,-01$ & 158,$00 ;-77$ & $170,-46$ \\
\hline \multirow[t]{2}{*}{ TP20 } & $\mathrm{C} 1$ & 020,39 & $145,70 \mathrm{NE}(\mathrm{o})$ & 264,23 & 100,$00 ;-125$ & $199,42 \mathrm{~W}$ & 182,15 & 199,$00 ;-42$ & 197,22 \\
\hline & $\mathrm{C} 2$ & 018,37 & & 267,23 & 100,$00 ;-125$ & & 183,17 & & 199,23 \\
\hline TP21 & $\mathrm{C} 2$ & 024,43 & $145,70 \mathrm{NE}(\mathrm{o})$ & 259,21 & 100,$00 ;-125$ & $199,42 \mathrm{~W}$ & 179,11 & 199,$00 ;-42$ & 191,21 \\
\hline TP25 & $\mathrm{C} 1$ & 339,65 & $85,60 \mathrm{~N}(\mathrm{o})$ & $182,-06$ & 100,$00 ;-125$ & $172,14 \mathrm{E}$ & $203,-12$ & 172,$00 ;+12$ & $204,-6$ \\
\hline ТР26 & $\mathrm{C} 1$ & 025,53 & $150,68 \mathrm{~N}(\mathrm{o})$ & 266,17 & 100,$00 ;-125$ & $013,46 \mathrm{~W}$ & 181,01 & 013,$00 ;+46$ & 185,09 \\
\hline TP37-m & $\mathrm{C} 1$ & 042,73 & $105,65 \mathrm{~N}(\mathrm{o})$ & 007,10 & 100,$00 ;-125$ & $071,11 \mathrm{~N}$ & $181,-20$ & 071,$00 ;+11$ & $179,-09$ \\
\hline \multirow[t]{2}{*}{ TP41 } & $\mathrm{C} 1$ & 019,33 & $135,30 \mathrm{~N}(\mathrm{o})$ & $247,-06$ & 100,$00 ;-125$ & $132,34 \mathrm{SW}$ & 182,22 & 132,$00 ;-34$ & $185,-05$ \\
\hline & $\mathrm{C} 2$ & 002,32 & & $261,-09$ & 100,$00 ;-125$ & & 197,23 & & $199,-08$ \\
\hline
\end{tabular}

For each component: orientation (declination, D and inclination, I) before tectonic correction (BTC), orientation after simple-bedding (So) correction (ATC), rotation axis used in the two-step bedding correction, orientation of the 'intermediate bedding' obtained after the first rotation and orientation of the palaeomagnetic component after the first and the second rotations.

axes are contained within these planes (except in TP21), showing rakes that range between 90 and $25^{\circ}$, and are folded following the same pattern as the palaeomagnetic components.

After bedding correction (the two-step bedding correction previously described was applied), $\mathrm{K}_{3}$ and $\mathrm{K}_{1}$ axes become subvertical and subhorizontal, respectively (Fig. 13b) and show a better grouping. This distribution suggests that magnetic fabrics pre-date Pyrenean folding and register the volcanic or volcanosedimentary fabric acquired during Stephanian times. A volcanic or volcano-sedimentary origin for the magnetic fabrics is also suggested by:

(i) Microstructural observations: thin-sections show flow evidences (such as oriented vacuoles and imbricated fragments) with an orientation that is 
Before bedding restoration
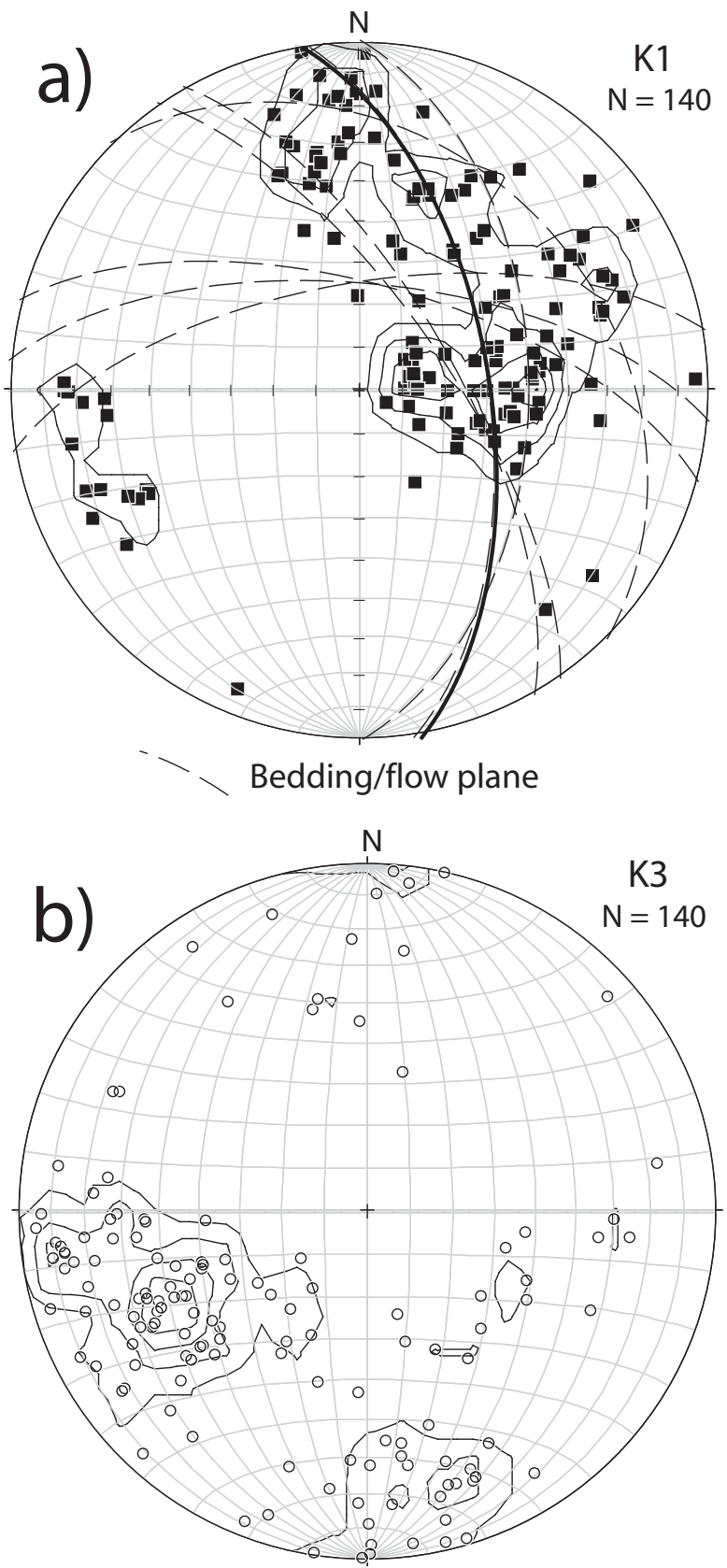

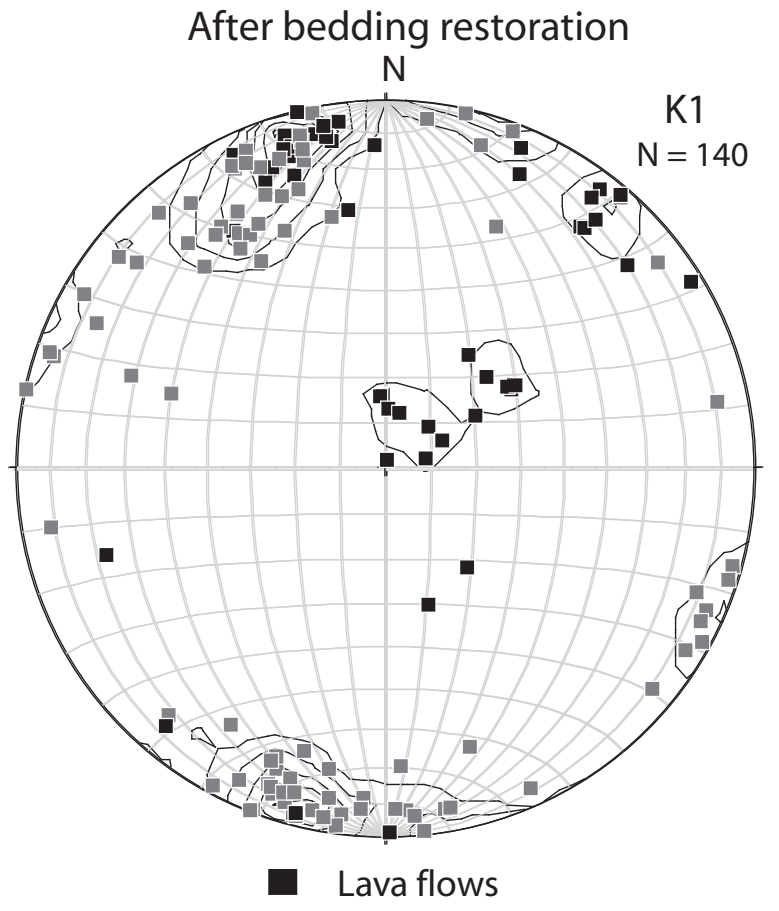

Pyroclastic deposits

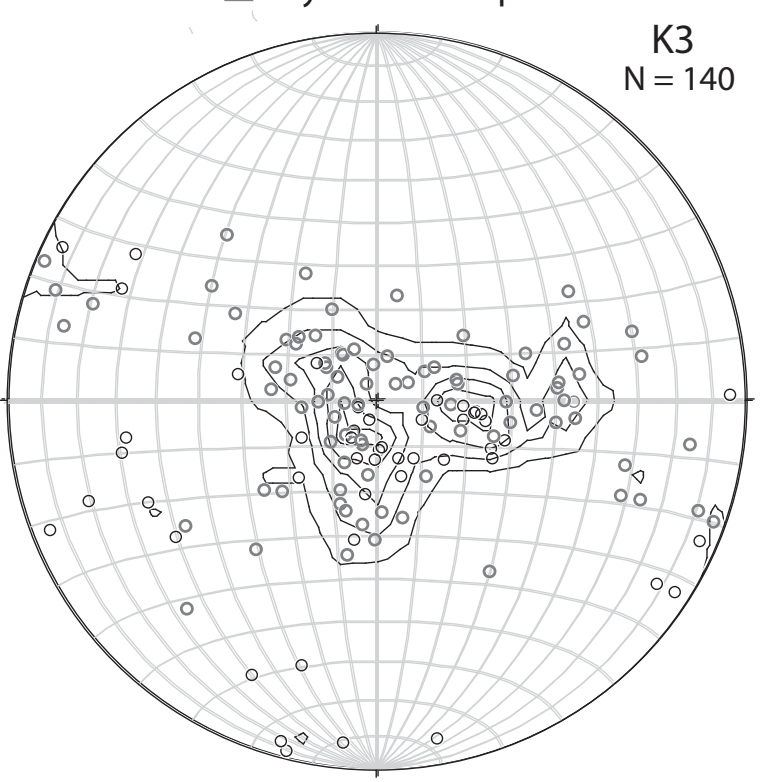

Figure 13. Stereoplots and density diagrams of $\mathrm{K}_{1}(\mathrm{a})$ and $\mathrm{K}_{3}$ (b) before and after bedding correction for all the measured samples.

consistent with the measured AMS; compressionrelated cleavage was not developed at the microscale.

(ii) Image analysis results that show a good correlation between the magnetic ellipsoid and the SPO of the different types of particles forming the lava flows and pyroclastic units.

A particular type of magnetic fabric has been obtained in site TP21, where $\mathrm{K}_{1}$ axes are almost perpendicular to the flow surface measured in the field. This kind of distribution could be expected: (i) in areas located close to the frontal boundary of the lava flows (Ellwood et al. 1993 and references therein) where particle rotation is a common process, or (ii) in the presence of single-domain magnetite causing an inverse fabric
(Rochette, 1988; Potter \& Stephenson, 1988). In the remaining sites, $\mathrm{K}_{3}$ axes are subperpendicular to bedding, showing some dispersion (Fig. 13b), and no significant differences are observed between the orientation of $\mathrm{K}_{3}$ in pyroclastic units and lava flows. After bedding restoration, $\mathrm{K}_{1}$ axes are subhorizontal and show two preferred orientations, NNW-SSE and NNE-SSW.

In regional studies, magnetic lineations in ignimbritic deposits have usually been interpreted as parallel to flow directions (Knight et al. 1986; MacDonald \& Palmer, 1990; Paquereau-Lebti, 2008), especially when constant trends are observed in different parts of the stratigraphic sequence and in the different levels forming one ignimbritic deposit. In our study area, $\mathrm{K}_{1}$ axes in both ignimbritic units and lava flows show a good 


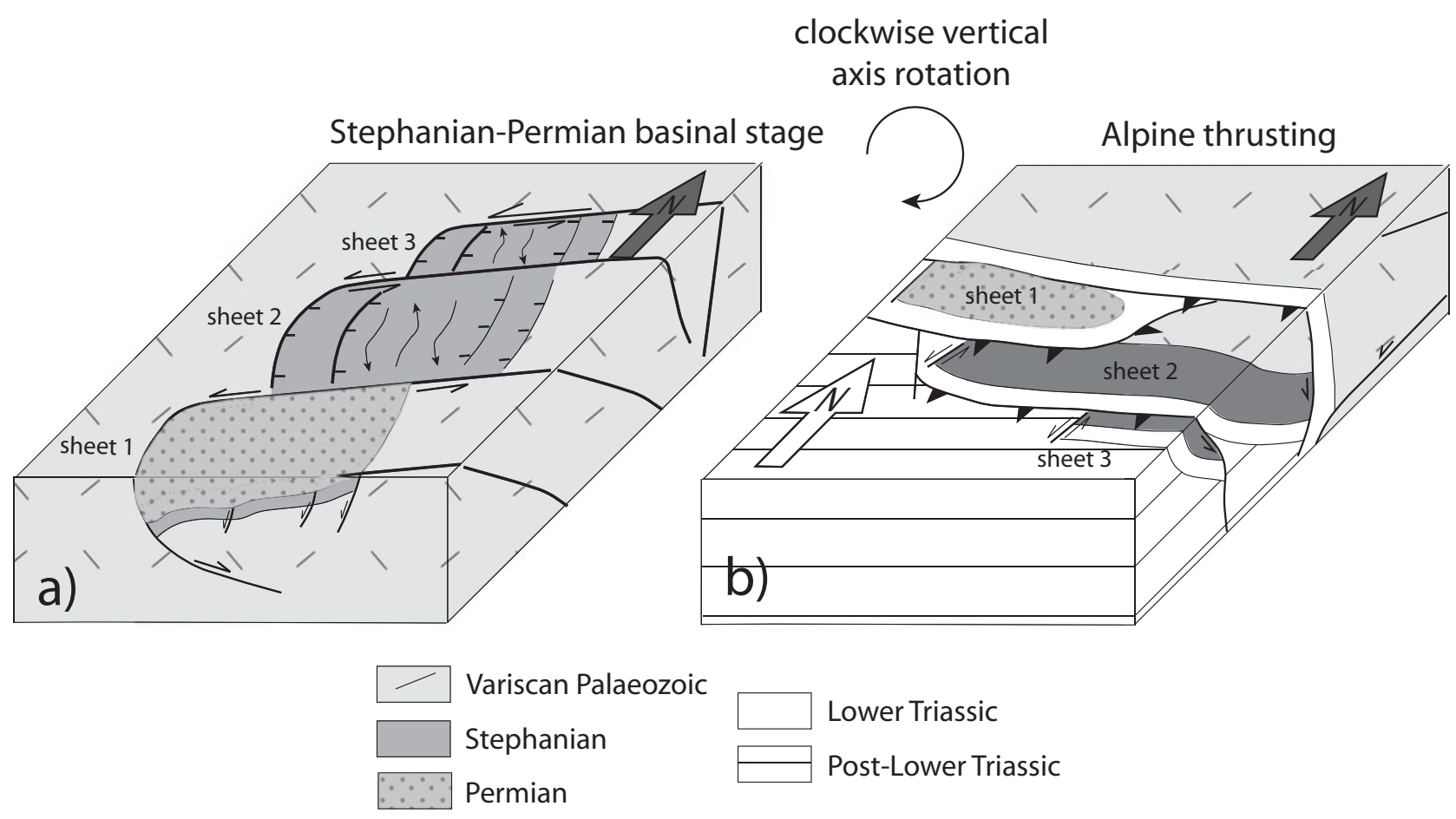

Figure 14. (a) Reconstruction of the basinal configuration during Stephanian-Permian times considering the magnetic fabrics and palaeomagnetic study. (b) Sketch showing the Alpine configuration of the Castejón-Laspaúles basin.

agreement and a constant orientation in (i) the different rock types, (ii) the different stratigraphic levels of the $\sim 500 \mathrm{~m}$ thick volcanic sequence and (iii) the different layers or flows sampled at every site. We consider that, in the absence of flow markers at the outcrop scale, this constant orientation can be interpreted in terms of flowparallel $\mathrm{K}_{1}$ axes that would indicate an average $\sim \mathrm{N}-\mathrm{S}$ trending flow (NNW-SSE- and NNE-SSW dominant flow directions). The different lithological types (lava flows and pyroclastic units) show the same flow pattern, probably indicating a constant source area. With regards to $\mathrm{K}_{3}$ axes, there is a higher dispersion, but a $\mathrm{N}-\mathrm{S}$-elongated maximum can be observed in the stereoplot that shows the whole dataset (see Fig. 13b). This maximum indicates foliation planes that are slightly imbricated towards the $\mathrm{N}$ and $\mathrm{S}$ with respect to bedding/flow planes, which would be in agreement with a dominant flow in this direction.

The restoration of the clockwise VAR of $+37^{\circ}$ detected by palaeomagnetic data would convert the inferred, average $\sim \mathrm{N}-\mathrm{S}$-trending flow (in present-day coordinates) into a NW-SE-trending flow pattern during Stephanian times. With regards to the flow sense, no definitive indications are given by the magnetic fabric results.

Furthermore, AMS ellipsoids could be interpreted in terms of dominant flow mechanisms (Cagnoli \& Tarling, 1997): laminar flows are usually related to triaxial AMS ellipsoids (well defined in sites TP25 and TP26, to the base and intermediate part of the volcanic sequence, see Fig. 1c), while turbulent deposits are characterized by oblate ellipsoids with welldefined $K_{3}$ axes and $K_{1}$ and $K_{2}$ axes distributed in a girdle (sites TP12, TP13 and TP37, ignimbrites and lava flows to the top of the volcanic sequence, see Fig. 1c).

\section{6.c. Implications for the tectonic-controlled volcanism in the Castejón-Laspaúles basin}

Field evidence and the new palaeomagnetic and magnetic fabric data shown in this work allow the inference of the following constraints with regards to the configuration of the Castejón-Laspaúles basin during Stephanian times:

(1) The comparison between the orientation of the obtained palaeomagnetic components and the Stephanian reference for the Iberian plate evidences an average clockwise rotation of $+37^{\circ}$ for the volcanic deposits. Similar rotations can be inferred from data in the overlying Triassic red beds (Bates, 1989; Izquierdo-Llavall et al. 2012a), indicating that the VAR took place mainly after Triassic times, probably owing to thrusting during the Pyrenean compressional stage (Fig. 14).

(2) Magnetic fabric results could be interpreted in terms of flow directions and would indicate a dominant $\mathrm{N}-\mathrm{S}$-trending flow direction (in present-day coordinates) for both lava flows and pyroclastic deposits. The expected flow pattern in a passive caldera (Martí \& Mitjavila, 1987, 1988) completely surrounded by active extensional faulting would impose a concentric flow pattern. Nonetheless, the existence of a preferred $\mathrm{N}-\mathrm{S}$-trending flow pattern can only be explained in the context of (i) a passive caldera where only E-Wstriking, straight and deep-rooted faults limiting the 
basin to the north and/or south are controlling magmatic emissions or (ii) an active caldera or volcanic building located north and/or south of the basin. There is no evidence of the presence of this sort of magmatic building and, therefore, we propose that the first option is the most plausible volcanic scenario. The existence of deep-rooted faults controlling magmatic emissions is consistent with the presence of granulitic xenoliths from the lower crust, detected by Arranz Yagüe, Galé-Bornao \& Lago-San Jose (1998) in adjacent areas.

(3) The inferred westward tilting of bedding and/or flow planes can be explained by the existence of normal faults, $\mathrm{N}-\mathrm{S}$-striking (in present-day coordinates), that controlled the infill geometry and limited the basin to the west.

(4) The proposed, dominant fault strikes acting during Stephanian times can be recognized in the presentday structure (Fig. 1b). The E-W-striking, deep faults controlling the magmatic emissions could be later reactivated as thrust planes during Alpine thrusting (as suggested by Saura \& Teixell, 1996 for adjacent Stephanian-Permian basins) while the N-S-striking normal faults could coincide with the oblique structures at the westward limits of thrust sheets (sheets 1 , 2 and 3 in Fig. 1b; see comments at the end of section 5.a.), reactivated as strike-slip faults during Pyrenean compression (Fig. 14a, b).

In summary, a distinction can be made between deep-rooted $\mathrm{E}-\mathrm{W}$ faults, probably responsible for magmatism, and shallow-rooted, listric faults of $\mathrm{N}-\mathrm{S}$ orientation (both in present-day coordinates), controlling the early tilting of beds. According to these inferred fault patterns, and considering the present-day architecture of the Nogueres Zone (in map view, the southern thrust sheets are shifted towards the east with respect to the thrust sheets located in a more northern position) the Stephanian-Permian basins can be envisaged as rhomb-shaped troughs between left-lateral strike-slip faults with extensional ends located to the west and eastward shifted for the more northern positions (Fig. 14a). This model is consistent with the basin geometry and the tectonic regime proposed by Soula, Lucas \& Bessiere (1979) for the French Permian basins, Bixel \& Lucas (1983) for the Western Pyrenees and Gisbert (unpub. Ph.D. thesis, Univ. Zaragoza, 1981) for the Eastern Pyrenees. It differs in the sense of shear from the model of Speksnijder (1985) for La Seu basin and in the regional tectonic regime and the role of the E-W-striking faults from the basin model proposed by Saura \& Teixell (2006).

\section{Conclusions}

The magnetic fabrics and palaeomagnetism dataset presented in this work led to the following conclusions:

(i) AMS ellipsoids show $\mathrm{K}_{3}$ axes that are usually perpendicular to bedding or flow planes and $\mathrm{K}_{1}$ is generally well grouped within these planes (Table 1). Image ana- lysis evidences that magnetic fabrics approximate the SPO of the fragments and minerals forming the different lithological units (Fig. 10).

(ii) Flow planes are in several sites oblique to the Alpine structure and this distribution is interpreted as being due to a westward tilting of the beds pre-dating compression.

(iii) The palaeomagnetic study (Figs 11,12) reveals the presence of one stable primary component clockwise rotated an average of $+37^{\circ}\left( \pm 32^{\circ}\right)$.

(iv) Magnetic fabrics are interpreted as being acquired during the emplacement or deposition of the volcanic and pyroclastic units and indicate a preferred $\mathrm{N}-\mathrm{S}$-trending flow direction (Fig. 13) in present-day coordinates. Both pyroclastic and volcanic units probably shared the same source area.

(v) Emissions were probably related to E-Wstriking, deep-rooted faults limiting the basins. These faults were coeval to the development of $\mathrm{N}-\mathrm{S}$-striking normal faults limiting the basins preferentially towards their western ends. The existence of these two fault sets and the distribution of basins are consistent with a sinistral shear regime during the development of the Castejón-Laspaúles basin (Fig. 14).

Acknowledgements. The authors thank Cristina García and Teresa Román for her help during field and laboratory work and Manuel Tricas for the preparation of thin-sections. This work forms part of the research projects CGL2009-08969 and CGL2006-05817 (Spanish Ministry of Education) and is included in the objectives of the pre-doctoral grant AP-20090554 (Esther Izquierdo) (Programa de formación de profesorado universitario, Spanish Ministry of Education). Funding from the Instituto de Estudios Altoaragoneses is also acknowledged. BOU acknowledges the JAEDOC postdoctoral programme financed with ESF. The authors acknowledge the careful and constructive revisions by B. Henry and an anonymous reviewer.

\section{References}

ALLERTON, S. 1998. Geometry and kinematics of verticalaxis rotations in fold and thrust belts. Tectonophysics 299, 15-30.

Arranz Yagüe, E., Galé-Bornao, C. \& Lago-San Jose, M. 1998. Características geológicas y petrográficas del magmatismo del sector Surpirenaico de Denuy (Huesca). Lucas Mallada 10, 45-65.

ARTHAUd, F. \& MATTE, P. 1977. Late Paleozoic strike-slip in southern Europe and northern Africa: result of a rightlateral shear zone between the Appalachians and the Urals. Geological Society of America Bulletin 88, 130520.

BATES, M. P. 1989. Paleomagnetic evidence for rotations and deformation in the Nogueras Zone, Central Southern Pyrenees, Spain. Journal of the Geological Society, London 146, 459-76.

BIXEL, F. \& LUCAS, CL. 1983. Magmatisme, tectonique et sédimentation dans les fossés stéphano-permiens des Pyrénées occidentales. Revue de Géologie Dynamique et Géographie Physique 24, 329-42.

Bourquin, S., Durand, M., Diez, J. B., Broutin, J. \& FIUTEAU, E. 2007. The Permian-Triassic boundary and lower Triassic sedimentation in the Western European 
basins: an overview. Journal of Iberian Geology 33, 221-36.

CAgnoli, B. \& TARling, D. H. 1997. The reliability of anisotropy of magnetic susceptibility (AMS) data as flow direction indicators in friable base surge and ignimbrite deposits: Italian examples. Journal of Volcanology and Geothermal Research 75, 309-20.

CAÑÓN-TAPIA, E. 2004. Anisotropy of magnetic susceptibility of lava flows and dykes: a historical account. In Magnetic Fabric: Methods and Applications (eds F. Martin-Hernandez, C. M. Luneburg, C. Aubourg \& M. Jackson), pp. 205-25. Geological Society of London, Special Publication no. 238.

CAÑ́N-TAPiA, E., WALKer, G. P. L. \& HERRERo-BerVERA, E. 1996. The internal structure of lava flows: insights from AMS measurements. Journal of Volcanology and Geothermal Research 70, 21-36.

CAÑón-TAPia, E., WALKer, G. P. L. \& Herrero-Bervera, E. 1997. The internal structure of lava flows- insights from AMS measurements II: Hawaiian pahoehoe, toothpaste lava and 'a'à. Journal of Volcanology and Geothermal Research 76, 19-46.

Cantarelli, V., Aldega, L., Corrado, S., Invernizzi, C. $\&$ CASAS-SAINZ, A. In press. Thermal history of the Aragón-Béarn basin (Late Paleozoic, western Pyrenees, Spain): insights into basin tectonic evolution. Italian Journal of Geosciences. Doi 10.3301.UG.2012.41

Cantarelli, V., CASAs-SAinz, A., Corrado, S., GisbertAguilar, J., InVERNIZZI, C. \& AldEGA, L. 2009. Late Paleozoic basin evolution in the Western Pyrenees. Geophysical Research Abstracts, EGU General Assembly 11, 8621.

Chadima, M. \& HroudA, F. 2006. Remasoft 3.0 a userfriendly paleomagnetic data browser and analyzer. Travaux Géophysiques 27, 20-1.

Deng, C., Zhu, R., JACKSON, M. J., Verosub, K. L. \& SINGER, M. J. 2001. Variability of the temperaturedependent susceptibility of the Holocene eolian deposits in the Chinese loess plateau: a pedogenesis indicator. Physics and Chemistry of the Earth, Part A: Solid Earth and Geodesy 26, 873-8.

DuNLOP, D. J. 1972. Magnetic mineralogy of unheated and heated red sediments by coercivity spectrum analysis. Geophysical Journal of the Royal Astronomical Society 27, 37-55

ELLWOOD, B. B. 1978. Flow and emplacement direction determined for selected basaltic bodies using magnetic susceptibility anisotropy measurements. Earth and Planetary Science Letters 41, 254-64.

Ellwood, B. B., Osipov, J. B., KAFAFy, A. M., Henry, B. \& Chlupakova, M. 1993. Primary fabrics in sedimentary and igneous rocks. In Magnetic Anisotropy of Rocks (eds D. Tarling \& F. Hrouda), pp. 95-168. London: Chapman and Hall.

FISHER, R. A. 1953. Dispersion on a sphere. Proceedings of the Royal Society of London A 217, 295-305.

García Senz, J., RAmirez Merino, J. I., NaVArro Juli, J. J., Rodríguez Santisteban, R., CAStaño, R. M., Leyva, F., García SAnsegundo, J. \& RAMirez DeL PozO, J. 2009a. Memoria Explicativa de la Hoja 213 (Pont de Suert). Madrid: Instituto Geológico y Minero de España.

GARcía SENZ, J., RAMIREZ MERINO, J. I., NAVARRo JULI, J. J., RODRÍGUEZ SANTISTEBAN, R., CASTAÑO, R. M., LEYVA, F., García SAnsegundo, J. \& RAmirez del Pozo, J. 2009b. Hoja 213 (Pont de Suert) del Mapa Geológico de España a Escala 1:50000. Madrid: Instituto Geológico y Minero de España.
Gisbert, J. 1983. El Pérmico de los Pirineos españoles. In Carbonífero y Pérmico de España (ed. C. Martínez Díaz). X Congreso Internacional de Estratigrafía y Geología del Carbonífero, Madrid.

GisBeRT, J. 1984. Las molasas tardihércinícas del Pireneo. In Libro Jubilar de J.M. Rios (ed. J. A. Comba), pp. 16886. Madrid: Instituto Geológico y Minero de España, 2.

Gisbert, J., MARTí, J. \& GASCÓN, F. 1985. Guía de la excursión al Stephaniense, Pérmico y Triásico inferior del Pirineo catalán. II Congreso de Estratigrafía y Paleogeografía del Pérmico y Triásico de España, La Seu d'Urgell, 79 pp.

HALVORSEN, E. 1974. The magnetic fabric of some dolerite intrusions, northeast Spitsbergen; implications for the emplacement. Earth and Planetary Science Letters 21, 127-33.

Henry, B., Plenier, G. \& CAmps, P. 2003. Postemplacement tilting of lava flows inferred from magnetic fabric study; the example of Oligocene lavas in the Jeanne d'Arc peninsula (Kerguelen Islands). Journal of Volcanology and Geothermal Research 127, 153-64.

HROUDA, F. 1994. A technique for the measurement of thermal changes of magnetic susceptibility of weakly magnetic rocks by the CS-2 apparatus and KLY-2 Kappabridge. Geophysical Journal International 118, 604-12.

Incoronato, A. F. T., AdDison, D. H., TARLing, G. N. \& PESCATORE, T. 1983. Magnetic fabric investigation of some pyroclastic deposits from the Phlegrean Fields, southern Italy. Nature 306, 461-3.

IzQUiERDo-Llavall, E., CASAS, A. M., Oliva-UrCia, B. \& SCHOLGER, R. 2012a. Are there vertical axis rotations associated with folded thrusts? Insights from a paleomagnetic study in the Nogueres Zone (Central Pyrenees). Contributions to Geophysics and Geodesy 42, Special Issue, 76-7.

IzQuierdo-Llavall, E., RomÁn-Berdiel, T., CASAS, A. M., Oliva-Urcia, B., Gil-Peña, I., Soto, R. \& JABALOY, A. 2012b. Magnetic fabric and structural study of the Eaux-Chaudes intrusion: understanding the Variscan deformation in the Western Axial Zone (Pyrenees). International Journal of Earth Sciences 101, 1817 34.

JELINEK, V. 1977. The statistical theory of measuring anisotropy of magnetic susceptibility of rocks and its application. Geofyzika, Brno

JELINEK, V. 1981. Characterization of the magnetic fabric of rocks. Tectonophysics 79, 63-70.

KHAN, M. A. 1962. The anisotropy of magnetic susceptibility of some igneous and metamorphic rocks. Journal of Geophysical Research 67, 2873-85.

KNight, M. D., WALKer, G. P. L., Ellwood, B. B. \& DieHL, J. F. 1986. Stratigraphy, paleomagnetic, and magnetic fabric of the Toba Tuffs: constraints on the source and eruptive styles. Journal of Geophysical Research 91, $10.355-10.382$.

Kruiver, P. P., DeKKERS, M. J. \& HeSLOP, D. 2001. Quantification of magnetic coercivity by analysis of acquisitions curves of isothermal remanent magnetisation. Earth and Planetary Science Letters 189, 269-76.

Lago, M., Arranz, E., Pocoví, A., Galé, C. \& GilIMAZ, A. 2004. Permian magmatism and basin dynamics in the southern Pyrenees: a record of the transition from late Variscan transtension to early Alpine extension. In Permo-Carboniferous Magmatism and Rifting in Europe (eds M. Wilson, E.-R. Neumann, G. R. Davies, M. J. Timmerman, M. Heeremans \& 
B. T. Larsen), pp. 439-64. Geological Society of London, Special Publication no. 223.

LOWRIE, W. 1990. Identification of ferromagnetic minerals in a rock by coercivity and unblocking temperature properties. Geophysical Research Letters 17, 15962.

LÜneburg, C. M., LAmpert, S. A., Hermann, I., Lebit, D., HIRT, A. M., CASEY, M. \& LOWRIE, W. 1999. Magnetic anisotropy, rock fabrics and finite strain in deformed sediments of SW Sardinia (Italy). Tectonophysics 307, $51-74$.

MacDonald, W. D. \& Palmer, H. C. 1990. Flow directions in ash-flow tuffs: a comparison of geological and magnetic susceptibility measurements, Tshirege member (upper Bandelier Tuff), Valles caldera, New Mexico, USA. Bulletin of Volcanology 53, 45-59.

MacDonald, W. D., Palmer, H. C., Deino, A. L. \& SHEN, P.-Y. 2012. Insights into deposition and deformation of intra-caldera ignimbrites, central Nevada. Journal of Volcanology and Geothermal Research 245-246, 4054.

Martí, J. \& MitjaVila, J. 1987. Calderas volcánicas pasivas: un ejemplo en el Estefaniense del Pirineo Catalán. Geogaceta 2, 19-22.

MARTí, J. \& MitJaViLA, J. 1988. El volcanismo tardihercínico del Pirineo Catalán, II: caracterización de la actividad explosiva. Acta Geológica Hispánica 23, 2131.

McCann, T., Pascal, C., Timmermann, M. J., Krzywiec, P., Lopez-Gomez, J., Wetzel, A., KraWCZYK, C. M., RiEKE, H. \& LAMARCHE, J. 2006. Post-Variscan (end Carboniferous-Early Permian) basin evolution in Western and Central Europe. In European Lithosphere Dynamics (eds D. G. Gee \& R. A. Stephenson), pp. 355-88. London: The Geological Society.

Molina-Garza, R. S., GEISSMAN, J. W. \& VAN DER VOO, R. 1989. Paleomagnetism of the Dewey Lake Formation (Late Permian), northwest Texas. The end of the Kiaman superchron in North America. Journal of Geophysical Research 94, 17881-8.

NAGTEGAAL, P. J. C. 1969. Sedimentology, paleoclimatology, and diagenesis of Post-Hercynian continental deposits in the south-Central Pyrenees, Spain. Leidse Geologische Mededelingen 42, 143-238.

Oliva-Urcia, B., Casas, A. M., Ramón, M. J., Leiss, B., MARIANI, E. \& ROMÁN-BERDIEL, T. 2012a. On the reliability of AMS in ilmenite-type granites: an insight from the Marimanha pluton, Central Pyrenees. Geophysical Journal International 189, 187-203.

Oliva-URCiA, B. \& PUEYO, E. L. 2007. Rotational basement kinematics deduced from remagnetized cover rocks (Internal Sierras, southwestern Pyrenees). Tectonics. 26, TC4014.

Osete, M. L. \& Palencia-Ortas, A. 2006. Polos paleomagnéticos de Iberia de los últimos 300 millones de años. Física de la Tierra 18, 157-81.

Osete, M. L., Rey, D., Villalaín, J. J. \& JuÁrez, M. T. 1997. The Late Carboniferous to Late Triassic segment of the apparent polar wander path of Iberia. Geologie en Mijnbouw 76, 105-19.

Paquereau-Lebti, P., Fornari, M., RoPerCh, P., ThOURET, J.-C. \& MACEDO, O. 2008. Paleomagnetism, magnetic fabric, and $40 \mathrm{Ar} / 39 \mathrm{Ar}$ dating of Pliocene and Quaternary ignimbrites in the Arequipa area, southern Peru. Bulletin of Volcanology 70, 977-97.

PARÉS, J. M., VAN DER VoO, R. \& Stamatakos, J. A. 1996. Paleomagnetism of Permian and Triassic red beds of NW Spain and implications for the tectonic evolution of the Asturian-Cantabrian arc. Geophysical Journal International 126, 893-901.

PetrovskÝ, E. \& KAPIČKA, A. 2006. On determination of the Curie point from thermomagnetic curves. Journal of Geophysical Research 111, B12S27. doi: 10.1029/2006JB004507.

Platt, J. P., Allerton, S., Kirker, A., Mandeville, C., MaYfield, A., PlatzMan, E. S. \& Rimi, A. 2003. The ultimate arc: differential displacement, oroclinal bending and vertical axis rotation in the External Betic-Rif arc. Tectonics 22, 1017.

Potter, D. K. \& Stephenson, A. 1988. Single-domain particles in rocks and magnetic fabric analysis. Geophysical Research Letters 15, 1097-100.

Pueyo, E. L., Millán, H. \& Pocoví, A. 2002. Rotation velocity of a thrust: a paleomagnetic study in the External Sierras (Southern Pyrenees). Sedimentary Geology 146, 191-208.

Pueyo, E. L., Pocoví, A., Millán, H. \& Sussman, A. J. 2004. Map view models for correcting and calculating shortening estimates in rotated thrust fronts using paleomagnetic data. In Orogenic Curvature: Integrating Paleomagnetic and Structural Analyses (eds. A. J. Sussman, A. B. Weil), pp. 57-71. Geological Society of America Special Paper no. 383.

ROCHETTE, P. 1988. Inverse magnetic fabric in carbonatebearing rocks. Earth and Planetary Science Letters $\mathbf{9 0}$, 229-37.

Rodríguez, L., Cuevas, J. \& TubíA, J. M. 2012. Structure of the Anayet Permian basin (Axial Zone, Central Pyrenees). Geophysical Research Abstracts, EGU General Assembly 14, 5422.

Román-Berdiel, T., Casas, A. M., Oliva-Urcia, B., PueYO, E. L. \& Rillo, C. 2004. The main Variscan deformation event in the Pyrenees: new data from the structural study of the Bielsa granite. Journal of Structural Geology 4, 659-77.

SAURA, E. \& TEIXELL, A. 2006. Inversion of small basins: effects on structural variations at the leading edge of the Axial Zone antiformal stack (Southern Pyrenees, Spain). Journal of Structural Geology 28, 190920.

SCHOTT, J. J. \& PerÉS, A. 1987. Paleomagnetism of PermoTriassic red beds from the Asturias and Cantabrian Chain (northern Spain): evidence for strong lower Tertiary remagnetizations. Tectonophysics 140, 17991.

SÉGURET, M. 1972. Etude tectonique des nappes et séries décollées de la partie centrale du versant sud des Pyrénées. Série géologie structurale $n^{\circ}$. 2. Montpellier: Publications de l'Université des Sciences et Techniques du Languedoc (Usetela), $155 \mathrm{pp}$.

Soula, J. C., LuCAS, C. \& Bessiere, G. 1979. Genesis and evolution of Permian and Triassic basins in the Pyrenees by regional simple shear acting on older Variscan structures: field evidence and experimental models. Tectonophysics 58, 3-4.

SPEKSNIJDER, A. 1985. Anatomy of a strike-slip fault controlled sedimentary basin, Permian of southern Pyrenees, Spain. Sedimentary Geology 44, 179-223.

StAmPfli, G. M., Mosar, J., MARQUER, D., MARChant, R., BAUDIN, T. \& BOREL, G. 1998. Subduction and obduction processes in the western Alps. In Continents and their Mantle Roots (eds A. Vauchez \& R. Meissner). Tectonophysics 296, 159-204.

Sussman, A. J., Pueyo, E. L., Chase, C. G., Mitra, G. \& WEIL, A. B. 2012. The impact of vertical-axis rotations on shortening estimates. Lithosphere 4, 383-94. 
TeIXell, A. 1996. The Ansó transect of the southern Pyrenees: basement and cover thrust geometries. Journal of Geophysical Research 102, 20.325-20.342.

VALERO-GARCÉS, B. \& GisBerT-Aguilar, J. 2004. La extensión post-varisca en la Cordillera Pirenaica. In Geología de España (ed. J. A. Vera), pp. 231-343. Madrid: SGE-IGME.

VAN DER VOO, R. 1969. Paleomagnetic evidence for the rotation of the Iberian Peninsula. Tectonophysics 7, 5-56.

VERWEY, E. J. W. 1939. Electronic conduction of magnetite $\left(\mathrm{Fe}_{3} \mathrm{O}_{4}\right)$ and its transition point at low temperatures. Nature 144, 327.
WATSON, G. S. 1956. A test for randomness of directions. Geophysical Supplements to the Monthly Notices of the Royal Astronomical Society 7, 160-1.

WeIL, A. B. \& Sussman, A. 2004. Classification of curved orogens based on the timing relationships between structural development and vertical-axis rotations. In Paleomagnetic and Structural Analysis of Orogenic Curvature (eds A. Sussman \& A. B. Weil), pp. 1-17. Geological Society of America, Special Paper no. 383.

ZIEGLER, P. A. 1988. Evolution of the Arctic-North Atlantic and the Western Tethys. American Association of Petroleum Geologists Memoir 43. 